\section{Quantifying regional effects of best management practices on nutrient losses from agricultural lands}

\author{
V.L. Roland II, A.M. Garcia, D.A. Saad, S.W. Ator, D. Robertson, and G. Schwarz
}

\begin{abstract}
Nitrogen $(\mathrm{N})$ and phosphorus $(\mathrm{P})$ losses from agricultural areas have degraded the water quality of downstream rivers, lakes, and oceans. As a result, investment in the adoption of agricultural best management practices (BMPs) has grown, but assessments of their effectiveness at large spatial scales have lagged. This study applies regional Spatially Referenced Regression On Watershed-attributes (SPARROW) models developed for the Midwest, Northeast, and Southeast United States to quantify potential regional effects of BMPs on nutrient losses from agricultural lands. These models were used because they account for specific BMPs in the prediction of instream nutrient loads. The BMPs included in the models were cover crops, no-till, and conservation tillage. Sensitivity testing for the BMPs on agricultural nutrient loads was done using simulations that varied the intensity of BMPs specified in each region. When the BMP intensity was increased 50\% relative to the 2012 intensity, the predicted agricultural load of total $\mathrm{P}$ decreased across all regions (4\% to 14\%). The predicted reduction in average P yields in the Midwest, Northeast, and Southeast was 706, 544, and 26 $\mathrm{kg} \mathrm{km}^{-2}$, respectively. Increasing BMPs by $50 \%$ decreased predicted agricultural total $\mathrm{N}$ loads by $3.5 \%$ in the Southeast but increased predicted $\mathrm{N}$ loads in the Midwest and Northeast by $4.7 \%$ and $1.8 \%$, respectively. Model-predicted average $\mathrm{N}$ yields increased by $402 \mathrm{~kg} \mathrm{~km}^{-2}$ and $302 \mathrm{~kg} \mathrm{~km}^{-2}$ in the Midwest and Northeast, respectively, and decreased in the Southeast by $329 \mathrm{~kg} \mathrm{~km}^{-2}$. In model simulations, cover crops were more effective at reducing $\mathrm{N}$ and $\mathrm{P}$ loads than the tillage BMPs despite lower intensity of implementation in 2012. However, at the regional scale of this investigation, implementation of BMPs result in only moderate predicted effects on agricultural nutrient loads
\end{abstract}

Key words: best management practice (BMP) implementation—nitrogen-phosphorustesting and assessment-water quality

One trade-off with increasing fertilizer use to enhance agricultural productivity can be an increase in nutrient (nitrogen [N] and phosphorus [P]) loss that often degrades the water quality of streams, rivers, lakes, and estuaries (Carpenter et al. 1998; Vitousek et al. 1997). In the United States, $67 \%$ of coastal systems, 33\% of streams, and $40 \%$ of lakes are impaired by excessive nutrient concentrations (Davidson et al. 2011). Nitrogen losses from agricultural fields are particularly problematic because fertilizer application rates have increased by $50 \%$ since the 1960 s (Cao et al. 2018).

The resulting degradation in water quality, ranging from toxic algal blooms affecting drinking water (Michalak et al. 2013) to "dead zones" affecting major fisheries (Diaz and Rosenberg 2008; Bricker et al. 2007; Kemp et al. 2005), has compromised human health and economic interest.

Conservation programs with the goal of improving downstream water quality have been implemented across most of the United States. Starting with increased funding for conservation in the 2002 Farm Security and Rural Investment Act (Congress.gov 2002), conservation planning has changed from

Received September 22, 2020; Revised April 19, 2021; Accepted May 27, 2021; Published online October 28, 2021. food security goals to maximizing environmental benefit (Becker 2002; Cox 2007). Within a mostly voluntary incentives-based framework, specific practices have been adopted into broad agronomic production, including nutrient management, planting winter cover crops, and conservation tillage. For example, in the Western Lake Erie Basin, recent farmer surveys show that cover crops are typically used at least once in a three-year crop (corn [Zea mays L.] or soybean [Glycine max L.]) rotation on $2 \%$ to $6 \%$ of areas in production (USDA NRCS 2017). Conservation activities have also been enhanced by regional and state programs, such as for the Chesapeake Bay watershed by the Chesapeake and Atlantic Coastal Bays Trust Fund, Chesapeake Bay Trust, and the National Fish and Wildlife Foundation's Chesapeake Bay Stewardship Fund. As of 2014, a wide range of agricultural best management practices (BMPs) covered more than 4.45 million ha in the Chesapeake Bay watershed-of this total area, conservation tillage was implemented on more than 809,000 ha, nutrient management on more than 607,000 ha, and cover crops on more than 161,000 ha (Sekellick et al. 2019).

Conservation practices provide environmental benefits through the reduction of nutrient and sediment losses by either optimizing nutrient inputs or by affecting transport pathways such as increasing infiltration or assimilation of nutrients (Schnepf and Cox 2006). Agricultural BMPs are incentivized through state and federal run conservation programs to reduce the loss of nutrients and sediment and in some cases reduce runoff. Many BMPs are designed to reduce sediment losses from nonpoint sources, which is a major factor in the deg-

Victor L. Roland II is a hydrologist with the US Geological Survey (USGS) Lower Mississippi -Gulf Water Science Center in Nashville, Tennessee. Ana Maria Garcia is a research hydrologist with the USGS South Atlantic Water Science Center in Raleigh, North Carolina. David A. Saad is a hydrologist with the USGS Wisconsin Water Science Center in Middleton, Wisconsin. Scott W. Ator is a hydrologist and water quality specialist with the USGS Maryland-Delaware-DC Water Science Center in Baltimore, Maryland. Dale Robertson is a research hydrologist with the USGS Wisconsin Water Science Center in Middleton, Wisconsin. Greg Schwarz is an economist with the USGS Water Mission Area in Reston, Virginia. 
radation of water quality in streams. In areas with high rates of soil erosion, elevated rates of $\mathrm{P}$ transport can be expected because sediment and $\mathrm{P}$ transport are closely related (Jamieson et al. 2003). Particulate P can account for a large fraction of the total $\mathrm{P}$ in runoff from agricultural fields, and measures that reduce soil losses from agricultural fields, such as a reduced tillage regime, can prove to be an effective strategy to limit P losses in runoff (Sharpley et al. 1987). In addition to reducing soil losses from agricultural fields, strategies that address the application of $\mathrm{P}$ fertilizers to upland surface soils pose obvious benefits for reducing P loads in streams (Staver and Brinsfield 2001; Richards and Baker 1997; Forster et al. 1985).

Systematically quantifying the water quality benefits of BMPs presents several challenges that have been noted elsewhere (Tomer and Locke 2011). The experimental design that supports the development of BMPs typically implements edge-offield assessments to quantify nutrient loss. Watershed scales are inherently heterogenous, which presents challenges to experimental control. Another aspect is that the design of BMPs has often been specific to an agricultural activity and a specific nutrient, but a broader assessment can uncover unintended impacts. For example, sediment control BMPs such as conservation tillage and no-till were designed to reduce the loss of sediment and sediment-bound nutrients from fields; however, these practices have been documented to increase the loss of dissolved forms of $\mathrm{N}$ (Daryanto et al. 2017; Golmohammadi et al. 2016) and P (Jarvie et al. 2017; Staver and Brinsfield 2001). Similarly, cover crops can have varying effects on nutrient losses based on the management strategy where they are implemented (Staver and Brinsfield 2001).

The US Geological Survey (USGS) National Water Quality Program (NWQP) has an objective to quantify trends in water quality in streams and rivers over large areas of the United States (Sprague et al. 2019), and identify drivers of water quality change in rivers and streams over large areas of the United States. One of the approaches the NWQP has used to identify drivers is the Spatially Referenced Regression On Watershed-attributes (SPARROW) model. The majority of past SPARROW models do not explicitly account for the effects of BMPs on water quality and loads in streams and rivers due to a lack of consistent data across entire model domains. One exception is the evaluation by García et al. (2016) of BMPs in a regional SPARROW model developed for the Midwest, which provided some empirical evidence of BMPs reducing $\mathrm{N}$ and $\mathrm{P}$ loads in streams in the Midwest.

To evaluate the effect of BMPs on water quality, the USGS conducted a study that sought to quantify the influence of specific conservation practices on instream $\mathrm{N}$ and $\mathrm{P}$ loads. The study was conducted using a novel application of preexisting regional SPARROW models from the Midwest, Northeast, and Southeast that included in their specifications terms that explicitly characterized the implementation of cover crop, conservation tillage, and no-till BMPs. The models were used to compute the percentage of change of predicted instream nutrient loads and concentrations, and average yields at the 2-digit hydrologic unit code (HUC2) regional scale resulting from scenario simulations that increased and decreased the intensity of BMP implementation in catchments within the modeling domains of each region. The results were then aggregated to major drainages in each of the model regions to assess the potential impacts of the simulated changes on water quality. The data, model input, and model output files that support the findings in this paper are available from Roland et al. (2021) and Saad et al. (2021).

\section{Materials and Methods}

Spatial Characterization of Best Management Practices. For this study, we evaluated a short list of BMPs for which county-level data are available from the USDA Natural Resources Conservation Service (NRCS) Cropland Data Layer (USDA NRCS 2015). These data were processed at the NHDPlus catchment scale as the percentage of land in each catchment to which BMPs were applied using methods described in Wieczorek et al. (2019). The conservation practice data set included attributes describing conservation tillage, no-till, and cover crops.

The SPARROW Model Framework. The SPARROW model is a hybrid statistical and mechanistic model typically used to estimate the movement of mass (e.g., nutrients and sediment) through the landscape under longterm, steady-state conditions (Schwarz et al. 2006). The model uses data describing catchment attributes such as constituent sources, characteristics of the catchment landscape, and stream or flow properties. Coefficients estimated during SPARROW model calibration provide insight into significant properties and processes that control the transport of a constituent through a watershed. Model-estimated source coefficients represent the delivery fraction of each source (if the source is in kilograms) or yield (if the source is in square kilometers) estimated for a catchment with average environmental characteristics in the basin. The magnitude of the coefficient for each land-to-water delivery variable indicates the sensitivity of the modeled constituent's delivery to the nearest stream to changes in that delivery variable. For example, a positive coefficient for a land-to-water delivery variable indicates this variable enhances the delivery of the constituent to streams. For delivery variables that are logarithmically transformed (such as those used for the BMP variables in this study), the interpretation of sensitivity can be quantified as follows: a coefficient value of $X$ means that a $1 \%$ difference between catchments in the value of the delivery variable (BMP) causes a X\% difference between catchments in the delivery of the constituent. The BMPs used in this study were treated as land-to-water delivery variables because they either promote or retard the transport of nutrients from upland agricultural fields to adjacent streams. Therefore, if $1 \%$ of a catchment had BMPs applied, the coefficient of the BMP directly describes how much the load was decreased (negative coefficient) or increased (positive coefficient) by the BMP.

Statistical Evaluation of Best Management Practice Variables from the 2012 Models. Coefficients in multivariable equations, such as those used in SPARROW models, can mislead interpretations of direct causeand-effect relations because individual or combinations of individual source variables may act as surrogates for other sources (Rawlings et al. 2001). The mechanistic mass-balance framework of SPARROW enables a relatively complete accounting of the nutrient sources and their delivery downstream, implying the overall inputs and delivery of these sources to monitoring locations in streams is reasonably estimated with the individual source and combination of delivery variable coefficients. However, the individual land-to-water delivery factors, such as BMP variables, included in a final calibrated SPARROW model and controlling model-computed delivery of each source to 
the stream may not represent all the factors operating in an actual ecosystem, complicating the determination of their individual causative effects (Robertson and Saad 2013). Evaluation of BMP land-to-water delivery variables was conducted in three steps. First, the Pearson correlation coefficient was computed for each of the BMP variables used in this study: cover crops, no-till, and conservation tillage. Next, an omitted variable test (OVT) (Davidson and MacKinnon 1993) was implemented to determine if coefficient estimates were unbiased. Lastly, a nonnested p-test (NNPT) (Davidson and MacKinnon 1993) was implemented to determine if the model specification was interpretable.

The OVT (Davidson and Mackinnon 1993) was used to determine if the model improved with the addition of omitted BMP variables. The test was conducted by regressing the SPARROW model residuals (in logarithm space) on the gradients of the fitted published models and additional gradients corresponding to the coefficients of omitted BMP variables. The additional gradients were derived from a specification of the models that included the omitted variables as additional land-to-water delivery variables, and the identical specification of the included BMP variable, but with the coefficients of the omitted variables set to zero. An F-test was used to determine the collective significance of the gradients of the omitted variables in the regression. If the null hypothesis of the test was rejected (the coefficients of the omitted variables were insignificant in the regression) then the included BMP coefficients and its associated variable represented an unbiased effect on water quality.

Finally, alternate $\mathrm{N}$ and $\mathrm{P}$ models were specified for each region that differed from the published models in that the retainedfor-final BMP variables were replaced with the excluded BMP variables. The two model specifications were compared to determine if nutrient load predictions were affected by a particular BMP or a combination of BMPs not included in the original model specification using a NNPT (Davidson and MacKinnon 1993) (figure 1). The test was conducted by creating a linear regression equation for each model that regresses model residuals (in logarithm space) on the gradient of coefficients for that model and a variable that represented the difference in the two models' predictions at monitoring sites. The test was evaluated by determining the

\section{Figure 1}

Schematic of the nonnested $p$-test (Davidson and MacKinnon 1993), which was used to evaluate the specification of best management practices (BMPs) in the Spatially Referenced Regression On Watershed-attributes (SPARROW) models.

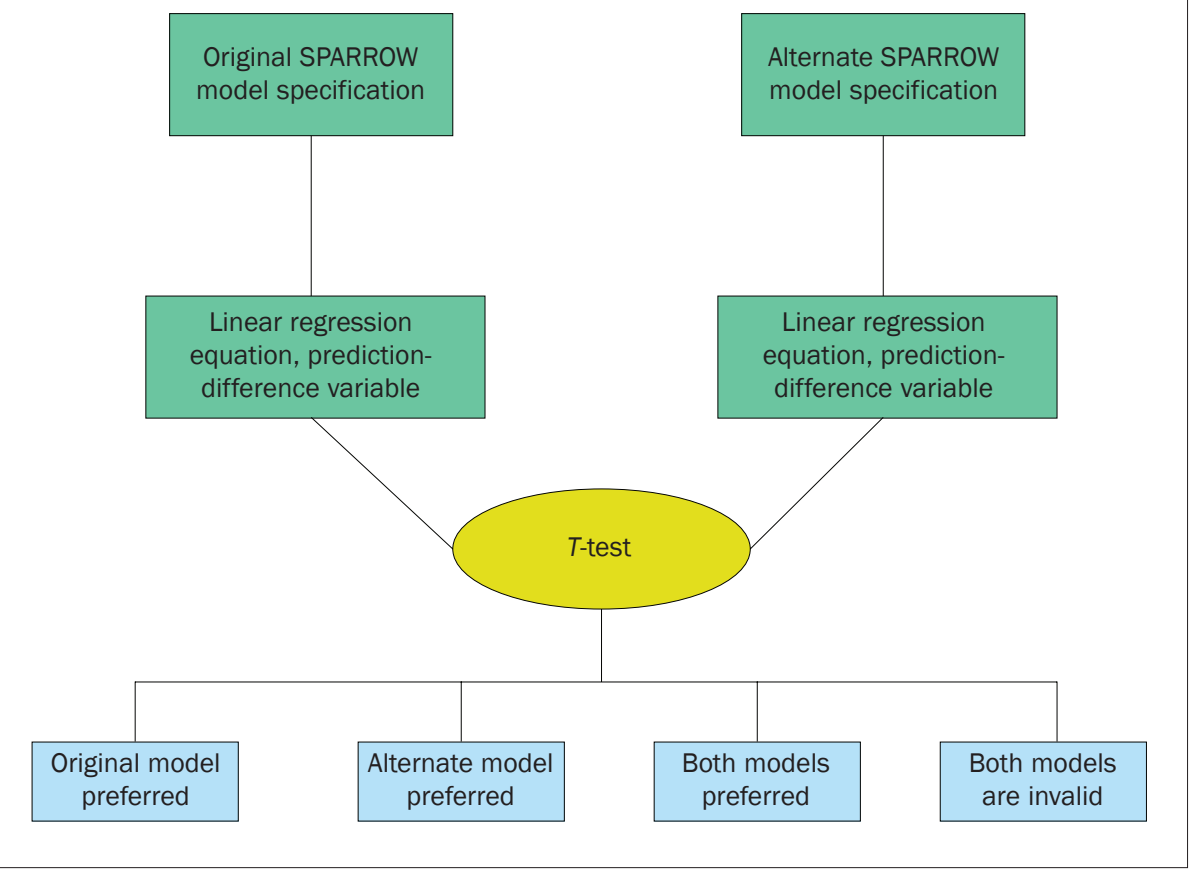

significance of the difference variable in the regression equations for both models using a $t$-test. If the results of the NNPT show the original model to be the preferred specification, then this is evidence that supports the interpretation of the estimated BMP coefficient of the original model as indicative of the specific causal effect of the BMP on water quality. A more detailed discussion of the specification testing and results is provided in the Supplemental Material.

The 2012 SPARROW Nitrogen and Phosphorus Models. In this study, published SPARROW models were used to estimate the effect of BMPs on the flux of nutrients in the Midwest, Northeast, and Southeast United States under conditions (i.e., nutrient inputs) representing 2012, the base year of the models (figure 2). Details of the regional models are published in Robertson and Saad (2019) (Midwest), Ator (2019) (Northeast), and Hoos and Roland (2019) (Southeast). These regional models were selected because agricultural BMPs were identified to have statistically significant effects on nutrient transport. A summary of BMP coefficient values estimated by the regional SPARROW nutrient models used in this study are presented in table 1.

The Southeast $\mathrm{N}$ model was specified with cover crops as the only statistically sig- nificant BMP land to water delivery variable (table 1). The model-estimated coefficient for the BMP variable was negative, indicating it reduces the delivery of $\mathrm{N}$ to streams by $0.166 \%$ for each percentage of the catchment area having cover crops. The negative value for cover crops was expected because cover crops have been shown to reduce $\mathrm{N}$ on croplands through vegetative $\mathrm{N}$ uptake (Hively et al. 2009). The P model also only had one statistically significant BMP variable-conservation tillage + no-till BMP. The creation and selection of this variable is described in Hoos and Roland (2019) for the Southeast. The conservation tillage + no-till BMP variable also had a negative coefficient value, indicating it reduces the delivery of $\mathrm{P}$ to streams by $0.135 \%$ for each percentage of the catchment area having cover crops. This was an expected result because reduced tillage - as a soil loss mitigation strategy-has been shown to reduce $\mathrm{P}$ loss (Smith et al. 2015; Richardson and King 1995).

The Northeast $\mathrm{N}$ model was specified with two BMP variables: cover crops and conservation tillage + no-till BMPs (table 1 ). The coefficients corresponding to these were negative for cover crops and positive for tillage practices (Ator 2019), indicating cover crops reduce the delivery of $\mathrm{N}$ to streams by $0.167 \%$ for each percentage of the catch- 


\section{Figure 2}

Spatially Referenced Regression On Watershed-attributes (SPARROW) model regions and HUC2 basins (Seaber et al. 1987) used in this study. The shaded regions of the map represent cultivated cropland area adapted from the National Land Cover Database (NLCD; Homer et al. 2015).

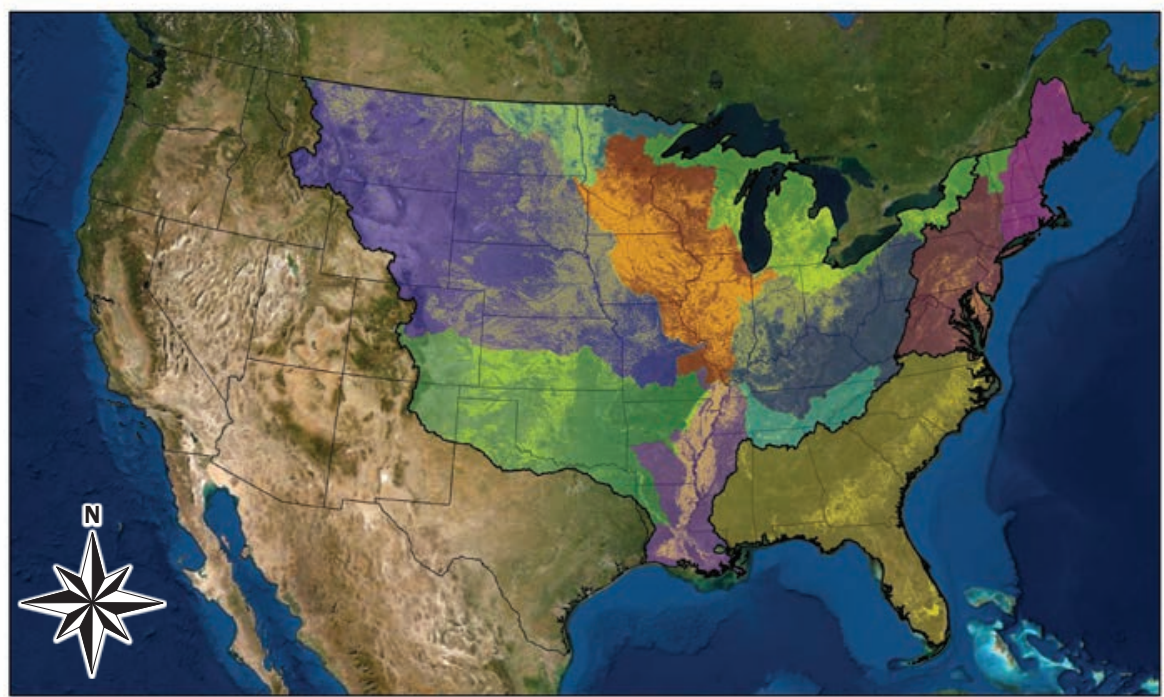

\section{Legend}

SPARROW modeling regions

\section{HUC2 region}

New England region

Mid-Atlantic region

South Atlantic-Gulf region

Great Lakes region

Ohio region

Tennessee region

Upper Mississippi region

Lower Mississippi region

Souris-Red-Rainy region

Missouri region

Arkansas-White-Red region ment area having cover crops and increase the delivery of $\mathrm{N}$ by $0.210 \%$ for each percentage of the catchment area having conservation tillage + no-till. Reduced tillage has been shown to increase $\mathrm{N}$ loss (Uribe et al. 2018); however, reduced tillage has also been shown to cause $\mathrm{N}$ loss to decrease (Tiessen et al. 2010). A positive effect (meaning reduced tillage increases the $\mathrm{N}$ loads) may occur because infiltration of dissolved $\mathrm{N}$ may happen more readily in undisturbed soils or have a negative impact (reduction in load from reduced tillage practices) because infiltration of dissolved $\mathrm{N}$ may be impeded by reduced hydraulic conductivity of tilled soils. The P model only had one significant $\mathrm{BMP}$ variable - conservation tillage + no-till BMP.The BMP in this model had a negative coefficient value, indicating it reduces the delivery of $\mathrm{P}$ to streams by $0.386 \%$ for each percentage of the catchment area where the BMP is implemented.

The statistically significant BMP variables in the Midwest SPARROW model used in this study were no-till for the $\mathrm{N}$ model and cover crops for the P model (table 1). The Midwest $\mathrm{N}$ model was used unchanged from the original version and had no-till with a positive coefficient, indicating no-till increases the delivery of $\mathrm{N}$ to streams by $0.124 \%$ for each percentage of the catchment area having no-till. The Midwest $\mathrm{P}$ model, however, was modified slightly to be more consistent with the other regional $\mathrm{P}$ models described in this paper. The original
Midwest P model included a BMP variable that represented reductions in $\mathrm{P}$ loss due to all BMPs implemented during the 2003 through 2006 time period compared to "no implementation" (USDA NRCS 2015). This BMP variable was intended to provide an indication of the expected aggregate benefits of the implementation of a suite of management practices. This paper attempts to evaluate the effects of individual BMPs, so it was decided that this variable be exchanged with other individual BMP variables, such as those included in the other regions. Based on this reevaluation, the original BMP variable was replaced with cover crops, which had a negative coefficient, indicating the BMP decreases the delivery of $\mathrm{P}$ to streams by $0.334 \%$ for each percentage of the catchment area with the BMP. Midwest $\mathrm{P}$ model results (estimation error and predictions) are very similar between the original model (Robertson and Saad 2019) and the modified model used in this study.

Quantifying Change in Instream Load with Change in Application Rates of Best Management Practice. Because of the nonlinearity of the log-transformed BMP variables in the SPARROW models, predictions from the model become unreliable when looking at extreme scenarios, e.g., reducing application rates of BMPs to zero or increasing application rates by $100 \%$. The BMP coefficients presented in table 1 therefore should not be used for a direct analytical assessment of nutrient load changes due to extreme changes in (doubling or eliminating) the application rates of BMPs. For this study, each of the BMP land-to-water delivery variables (conservation tillage, no-till, and cover crops) were quantified as the fraction

\section{Table 1}

Regional nitrogen $(\mathrm{N})$ and phosphorus $(\mathrm{P})$ SPARROW model estimated best management practice (BMP) coefficient values for conditions in 2012.

\begin{tabular}{lllcc}
\hline Region & Model & BMP & Coefficient & P-value \\
\hline Southeast & $\mathrm{N}$ & Cover crops & -0.166 & $<0.0001$ \\
Southeast & $\mathrm{P}$ & Conservation tillage + no-till & -0.135 & $<0.0001$ \\
Northeast & $\mathrm{N}$ & Cover crops & -0.167 & 0.091 \\
& & Conservation tillage + no-till & 0.210 & 0.099 \\
Northeast & $\mathrm{P}$ & Conservation tillage + no-till & -0.386 & $<0.001$ \\
Midwest & $\mathrm{N}$ & No-till & 0.124 & 0.013 \\
Midwest & $\mathrm{P}$ & Cover crops & -0.334 & 0.033
\end{tabular}


of the catchment agricultural area covered by the BMP. A summary of the basin area with BMPs used in the 2012 SPARROW models for each 2-digit hydrologic unit code (HUC2) is presented in table 2. The basin areas with each BMP were increased and decreased by a factor of 1.5 and 0.5 . If increasing the BMP fraction by a factor of 1.5 exceeded the fraction of agricultural land in the catchment, the cover crop fraction was limited to the fraction of agricultural land (avoiding the issue of having more no-till area or cover crop area than agricultural land area in a catchment). Changes to instream loads due to changes in BMPs were then simulated using the calibrated SPARROW model coefficients reported in table 1 with the increased or decreased BMP values. The percentage change relative to the load predicted by the original calibrated model was calculated using equation 1:

Relative percentage change $=$

BMP modified load - Original model load Original model load $\times 100$.

Percentage increases and decreases in the sum of incremental loads were reported at the HUC2 scale (Seaber et al. 1987) and for the Lake Erie, Chesapeake Bay, and Gulf of Mexico basins. Efficiencies were also reported as kilograms of instream load nutrient reduction per square kilometer of additional BMP implemented or removed $\left(\mathrm{kg} \mathrm{km}{ }^{-2}\right)$ and were compared to other published values. The flow-weighted mean concentration (FWMC) was computed from load for each of the regional models using equation 2 :

$$
\text { FWMC }=\frac{\text { Incremental nutrient load }}{\text { Incremental flow }}
$$

The FWMC can be interpreted as the nutrient concentrations of all streams that contribute to the river network.

The simulated loads delivered to Western Lake Erie, the Chesapeake Bay, and to the Gulf of Mexico under these BMP scenarios were calculated by aggregating the simulated delivered loads from each stream reach in the respective watersheds, and results were then compared with the results of regional Conservation Effects Assessment Project (CEAP) studies for the Great Lakes (USDA NRCS 2011), Chesapeake Bay (USDA NRCS 2013), and the Gulf of Mexico (USDA NRCS 2014). The comparisons are qualitative rather than quantitative, however, as the approach used in the CEAP studies is not directly comparable to the approach in this study: the CEAP studies evaluated the overall effectiveness of a wider range of BMPs on the landscape, and identified areas where additional BMPs could result in additional load reductions. Nevertheless, the qualitative comparisons provide additional context to the findings of this study about the general trajectory of water quality in response to the growing adoption of BMPs.

\section{Results and Discussion}

While data sets representative of multiple specific BMPs were tested during model specification as described, each regional model was limited in its final form. For the Midwest N model and the Southeast P models, testing demonstrated that the BMP data sets were representative of other collinear soil conservation BMPs. For the Southeast N model and both Northeast models, the variable testing confirmed that distinct processes were represented with each of the BMPs. For purposes of this study in this discussion, we use the term BMP for broad practices that are surrogate for multiple activities and we reserve the name of the specific BMP (such as cover crops or no-till) to models that are representative of the specific activity.

Nitrogen. Increasing the intensity of BMPs in the Midwest by 50\% from 2012 levels increased agricultural $\mathrm{N}$ loads by a range of $3.24 \%$ to $4.73 \%$ among HUC2s, and overall $\mathrm{N}$ loads by a range of $1.52 \%$ to $3.14 \%$ (figure 3). The Ohio River basin (HUC 05) had the largest percentage change in agricultural $\mathrm{N}$ loads and the Upper Mississippi River basin (HUC 07) had the largest overall change in overall $\mathrm{N}$ loads. The increase in

\section{Table 2}

2012 Spatially Referenced Regression On Watershed-attributes (SPARROW) model summary of the basin area with best management practices (BMPs) for each 2-digit HUC used in increasing and decreasing BMP intensity simulation scenarios.

\begin{tabular}{|c|c|c|c|c|c|c|c|c|}
\hline \multirow[b]{2}{*}{$\begin{array}{l}\text { Regional } \\
\text { SPARROW } \\
\text { model }\end{array}$} & \multirow[b]{2}{*}{ Basin name } & \multirow[b]{2}{*}{ HUC2 } & \multicolumn{6}{|c|}{ Basin area $\left(\mathbf{k m}^{2}\right)$} \\
\hline & & & Total & Agriculture & $\begin{array}{l}\text { Cover } \\
\text { crops }\end{array}$ & $\begin{array}{l}\text { Conser- } \\
\text { vation } \\
\text { tillage }\end{array}$ & No-till & $\begin{array}{l}\text { Conser- } \\
\text { vation } \\
\text { tillage } \\
+ \text { no-till }\end{array}$ \\
\hline Northeast & New England region & 01 & 95,763 & 7,115 & 317 & 162 & 130 & 292 \\
\hline Northeast & Mid-Atlantic region & 02 & 232,809 & 57,911 & 4,368 & 3,877 & 12,049 & 15,926 \\
\hline Southeast & South Atlantic-Gulf region & 03 & 628,360 & 106,768 & 5,021 & 10,205 & 16,067 & 26,272 \\
\hline Midwest & Great Lakes region & 04 & 323,974 & 93,808 & 3,910 & - & 16,664 & - \\
\hline Midwest & Ohio region & 05 & 420,482 & 152,655 & 4,739 & - & 42,513 & - \\
\hline Midwest & Tennessee region & 06 & 105,952 & 23,583 & 740 & - & 4,480 & - \\
\hline Midwest & Upper Mississippi region & 07 & 490,971 & 287,262 & 5,393 & - & 47,563 & - \\
\hline Midwest & Lower Mississippi region & 08 & 285,337 & 96,018 & 1,647 & - & 16,401 & - \\
\hline Midwest & Souris-Red-Rainy region & 09 & 204,534 & 79,316 & 842 & - & 8,676 & - \\
\hline Midwest & Missouri region & 10 & $1,314,197$ & 414,283 & 5,045 & - & 180,348 & - \\
\hline Midwest & Arkansas-White-Red region & 11 & 636,003 & 178,638 & 2.759 & - & 36,733 & - \\
\hline
\end{tabular}




\section{Figure 3}

Regional Spatially Referenced Regression On Watershed-attributes (SPARROW) model results for nitrogen (N) loads from applied increases and decreases of best management practice (BMP) implementation. (a) N load percentage of change from agricultural sources with a $50 \%$ increase in BMP intensity; (b) N load percentage of change from all nutrient sources with a $50 \%$ increase in BMP intensity; (c) N load percentage of change from agricultural sources with a $50 \%$ decrease in BMP intensity; (d) N load percentage of change from all nutrient sources with a $50 \%$ decrease in BMP intensity. Shaded regions of the maps represent HUC2 basins (Seaber et al. 1987) used in this study.

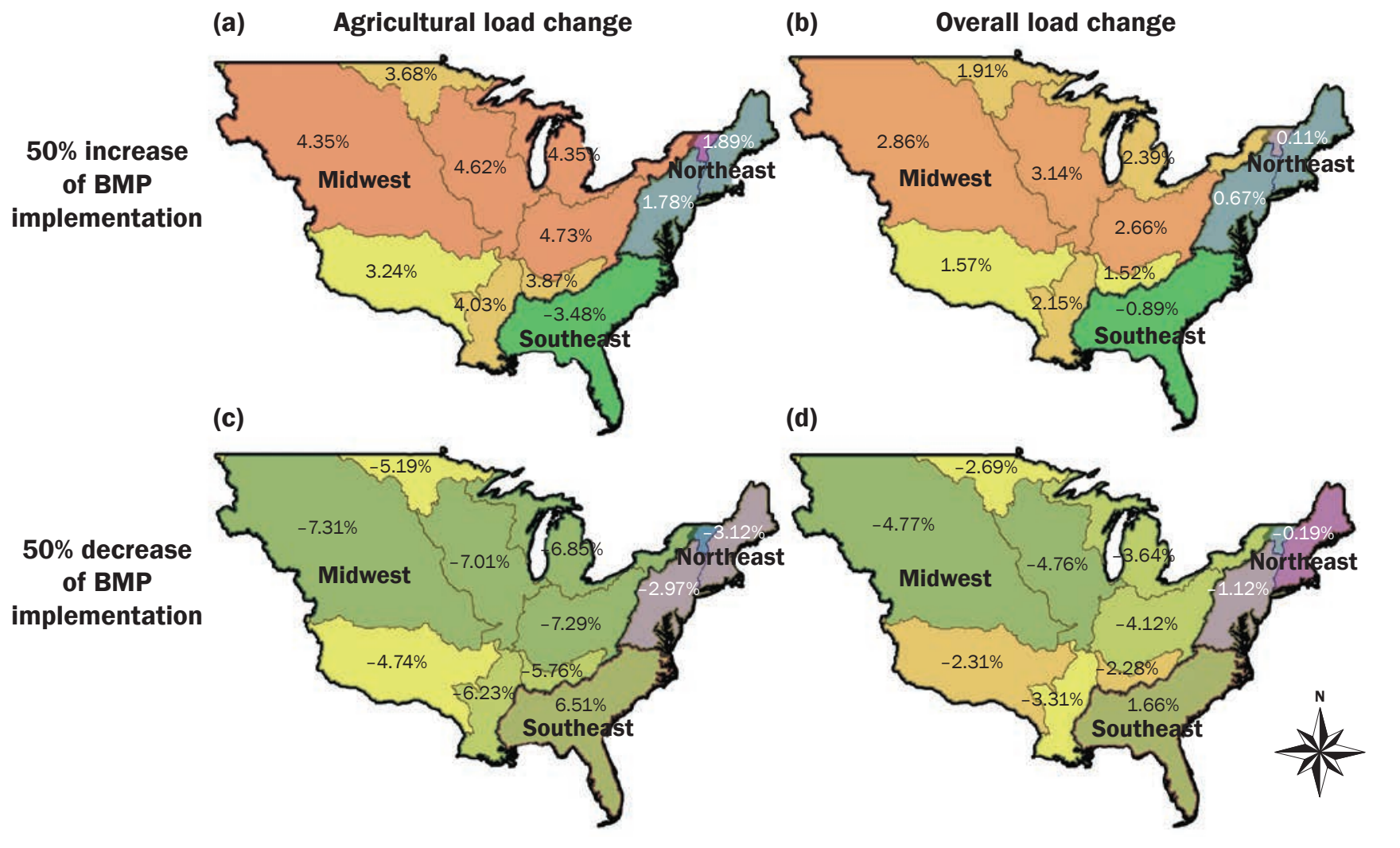

BMPs resulted in an average increase in agricultural $\mathrm{N}$ yield of $402 \mathrm{~kg} \mathrm{~km}^{-2}$. When BMP intensity was decreased by $50 \%$, agricultural $\mathrm{N}$ loads decreased by a range of $4.74 \%$ to $7.31 \%$ among HUC2s, and overall $\mathrm{N}$ loads decreased by a range of $2.28 \%$ to $4.77 \%$. The largest change in agricultural $\mathrm{N}$ loads and overall $\mathrm{N}$ loads occurred in the Missouri River basin (HUC 10). Base FWMC of N in Midwest HUC2s ranged from 1.243 to $4.466 \mathrm{mg} \mathrm{L}^{-1}$ (table 3). A $50 \%$ increase in BMPS increased $\mathrm{N}$ concentrations by 0.019 to $0.140 \mathrm{mg} \mathrm{L}^{-1}$, and a $50 \%$ decrease in BMPs decreased $\mathrm{N}$ concentrations by 0.028 to $0.213 \mathrm{mg} \mathrm{L}^{-1}$.

Alternate model specifications could not be tested in the $\mathrm{N}$ model because it included all of the BMPs tested in this study. Because the Northeast $\mathrm{N}$ model has two BMPs with different coefficient signs, results from BMP changes reflect the net effect from changes in both BMP variables (figure 3). The two HUC2s in the Northeast region (New
England-HUC 01 and Mid-Atlantic-HUC 02) had similar patterns of N-load change with BMP-intensity change, with slightly larger magnitude for New England. On average for the Northeast, increasing BMPs by $50 \%$ increased agricultural $\mathrm{N}$ loads from $1.78 \%$ to $1.89 \%$ and overall $\mathrm{N}$ loads from $0.11 \%$ to $0.67 \%$, and increased agricultural $\mathrm{N}$ yield by $302 \mathrm{~kg} \mathrm{~km}^{-2}$. When calculated for cover crops and conservation tillage + no-till individually, increasing cover crops by $50 \%$ decreased agricultural $\mathrm{N}$ yield by $790 \mathrm{~kg}$ $\mathrm{km}^{-2}$, and increasing conservation tillage + no-till by $50 \%$ increased agricultural $\mathrm{N}$ yield by $532 \mathrm{~kg} \mathrm{~km}^{-2}$. Decreasing BMPs by $50 \%$ decreased agricultural $\mathrm{N}$ load from $2.97 \%$ to $3.12 \%$, and overall $\mathrm{N}$ load from $0.19 \%$ to $1.12 \%$. Base FWMC of $\mathrm{N}$ in Northeast HUC2s were $0.663 \mathrm{mg} \mathrm{L}^{-1}$ and $1.654 \mathrm{mg}$ $\mathrm{L}^{-1}$ (table 3). A 50\% increase in both BMPs increased $\mathrm{N}$ concentrations by 0.001 to $0.011 \mathrm{mg} \mathrm{L}^{-1}$, and a $50 \%$ decrease in BMPs decreased $\mathrm{N}$ concentrations by 0.001 to $0.019 \mathrm{mg} \mathrm{L}^{-1}$.

Increasing cover crop intensity by $50 \%$ in the Southeast $\mathrm{N}$ model (the South Atlantic-Gulf Region-HUC 03) decreased agricultural $\mathrm{N}$ load by 3.5\% and decreased overall $\mathrm{N}$ load by $0.89 \%$ (figure 3). A $50 \%$ increase in cover crops decreased agricultural $\mathrm{N}$ yields by $329 \mathrm{~kg} \mathrm{~km}^{-2}$. Decreasing the amount of cover crops in the region resulted in a $6.51 \%$ increase in agricultural $\mathrm{N}$ loads and a $1.66 \%$ increase in overall $\mathrm{N}$ loads. The base FWMC of $\mathrm{N}$ in the Southeast was $0.319 \mathrm{mg} \mathrm{L}^{-1}$ (table 3). A $50 \%$ increase in cover crops decreased the $\mathrm{N}$ concentration by $0.011 \mathrm{mg} \mathrm{L}^{-1}$, and a $50 \%$ decrease in cover crops increased the $\mathrm{N}$ concentration by $0.021 \mathrm{mg} \mathrm{L}^{-1}$.

The simulations predict decreased agricultural $\mathrm{N}$ yields with cover crops with some regional variation: the effect predicted for agricultural fields in the Northeast is twice that predicted for the Southeast. There are 
several possible explanations for the regional variation that include seasonal influences. First, in colder climates representative of the Northeast we expect a longer season for cover crop implementation. This would require additional fertilization to produce these crops, and depending on nutrient management a surplus of inputs could dominate the impact of the BMP. In addition, as average temperatures increase in the north-south direction, we could also see an increase in $\mathrm{N}$ uptake and denitrification, which favors lower $\mathrm{N}$ yields in the Southeast.

Phosphorus. In the Midwest P model, increasing BMPs by $50 \%$ from 2012 conditions resulted in a $3.97 \%$ to $8.77 \%$ decrease in agricultural $\mathrm{P}$ loads and a $2.63 \%$ to $4.38 \%$ decrease in overall P loads (figure 4). The agricultural load decreased most in the Great Lakes Region (HUC 04), and the overall P load decreased most in the Upper Mississippi Region (HUC 07). A 50\% increase in BMP intensity resulted in a $706 \mathrm{~kg} \mathrm{~km}^{-2}$ decrease in agricultural $\mathrm{P}$ yields. When BMP intensity was decreased by $50 \%$, there was a $7.59 \%$ to $14.2 \%$ increase in agricultural $\mathrm{P}$ loads and a $3.4 \%$ to $6.44 \%$ increase in overall $\mathrm{P}$ loads. The base FWMC in Midwest HUC2s ranged from 0.135 to $0.525 \mathrm{mg} \mathrm{L}^{-1}$ (table 3 ). A 50\% increase in BMPs decreased P concentrations by 0.005 to $0.020 \mathrm{mg} \mathrm{L}^{-1}$, and a $50 \%$ decrease in BMPs increased $\mathrm{P}$ concentrations by 0.009 to $0.028 \mathrm{mg} \mathrm{L}^{-1}$.
In the Northeast $\mathrm{P}$ model, increasing conservation tillage + no-till intensity by $50 \%$ resulted in a decrease in the agricultural $\mathrm{P}$ load of about $14 \%$ for both Northeast HUC2s and by a range of $2.23 \%$ to $3.57 \%$ for the overall $\mathrm{P}$ load (figure 4). Increasing conservation tillage + no-till intensity from base 2012 levels resulted in a $544 \mathrm{~kg} \mathrm{~km}^{-2}$ reduction in agricultural $\mathrm{P}$ yields. When conservation tillage + no-till intensity was decreased by $50 \%$ the agricultural $\mathrm{P}$ load increased by approximately $30 \%$ in both HUC2s, and the overall P load increased by a range of from $4.7 \%$ to $7.6 \%$ in the region (figure 4). Base FWMC in the Northeast HUC2s were $0.050 \mathrm{mg} \mathrm{L}^{-1}$ and $0.141 \mathrm{mg}$ $\mathrm{L}^{-1}$ (table 3). A $50 \%$ increase in conservation tillage + no-till decreased $\mathrm{P}$ concentrations by $0.001 \mathrm{mg} \mathrm{L}^{-1}$ and $0.005 \mathrm{mg} \mathrm{L}^{-1}$, and a $50 \%$ decrease increased $\mathrm{P}$ concentrations by 0.002 $\mathrm{mg} \mathrm{L}^{-1}$ and $0.011 \mathrm{mg} \mathrm{L}^{-1}$.

In the Southeast P model, increasing BMP intensity by $50 \%$ resulted in a decrease in the agricultural $\mathrm{P}$ load of $4.8 \%$ and $1.5 \%$ for the overall $\mathrm{P}$ load (figure 4). Increasing BMP intensity from base 2012 levels resulted in a $26 \mathrm{~kg} \mathrm{~km}^{-2}$ decrease in agricultural $\mathrm{P}$ yields. When BMP intensity was decreased by $50 \%$, the agricultural $\mathrm{P}$ load increased by $8.9 \%$ and the overall $\mathrm{P}$ load increased $2.8 \%$. Base FWMC for P in the Southeast HUC2 was $0.048 \mathrm{mg} \mathrm{L}^{-1}$ (table 3). A $50 \%$ increase in BMPs decreased $\mathrm{P}$ concentrations by
$0.002 \mathrm{mg} \mathrm{L}^{-1}$, and a $50 \%$ decrease in BMPs increased $\mathrm{P}$ concentrations by $0.004 \mathrm{mg} \mathrm{L}^{-1}$.

The coefficients of the BMP variables in each model demonstrate the effects of enhancing (positive coefficient) or diminishing (negative coefficient) delivery of nutrients caused by practices applied in the watershed. Cover crops in the Southeast and Northeast $\mathrm{N}$ models had similar negative coefficient values, which indicated $\mathrm{N}$ loads decreased where cover crops were implemented. Based on these results, the changes in $\mathrm{N}$ loads were similar as the application rate of cover crops increased in the two regions. The diminishing effect of cover crops on $\mathrm{N}$ loads agreed with the findings of many investigators (Hanrahan et al. 2018; Lee et al. 2016; Yeo et al. 2014). The Northeast N model also included reduced tillage practices (conservation tillage + no-till) with a positive coefficient; the enhancing effects of reduced tillage practices on $\mathrm{N}$ loads agreed with findings of Baker (1993) and Alberts and Spomer (1985). The combined effect of increasing intensity of both cover crops and reduced tillage practices in the Northeast was to increase $\mathrm{N}$ loss to streams. The effects of reduced tillage on $\mathrm{N}$ loads were nearly twice as large in the Northeast as compared to no-till practices in the Midwest.

The coefficients of reduced tillage and cover crops were negative in $\mathrm{P}$ models for all areas, suggesting these BMPs effectively reduced $\mathrm{P}$ losses. Reduced tillage was a sig-

\section{Table 3}

Flow-weighted mean concentrations of nitrogen and total phosphorus by HUC2. Bolded entries indicate increasing concentrations with increasing best management practice (BMP) intensity. All concentrations are in milligrams per liter ( $\left.\mathrm{mg} \mathrm{L}^{-1}\right)$.

\begin{tabular}{|c|c|c|c|c|c|c|c|}
\hline \multirow[b]{2}{*}{ HUC2 } & \multirow[b]{2}{*}{$\begin{array}{l}\text { Regional } \\
\text { SPARROW } \\
\text { model } \\
\end{array}$} & \multicolumn{3}{|c|}{ Nitrogen concentration } & \multicolumn{3}{|c|}{ Phosphorus concentration } \\
\hline & & $\begin{array}{l}50 \% \\
\text { decrease } \\
\text { in BMP }\end{array}$ & $\begin{array}{l}\text { Base } \\
\text { conditions }\end{array}$ & $\begin{array}{l}50 \% \\
\text { increase } \\
\text { in BMP }\end{array}$ & $\begin{array}{l}\mathbf{5 0} \% \\
\text { decrease } \\
\text { in BMP }\end{array}$ & $\begin{array}{l}\text { Base } \\
\text { conditions }\end{array}$ & $\begin{array}{l}50 \% \\
\text { increase } \\
\text { in BMP }\end{array}$ \\
\hline 01 & Northeast & 0.662 & 0.663 & 0.664 & 0.052 & 0.050 & 0.049 \\
\hline 02 & Northeast & 1.636 & 1.654 & 1.666 & 0.151 & 0.141 & 0.136 \\
\hline 03 & Southeast & 0.340 & 0.319 & 0.308 & 0.052 & 0.048 & 0.045 \\
\hline 06 & Midwest & 1.215 & 1.243 & 1.262 & 0.226 & 0.218 & 0.212 \\
\hline 07 & Midwest & 4.253 & 4.466 & 4.606 & 0.453 & 0.426 & 0.407 \\
\hline 08 & Midwest & 1.311 & 1.356 & 1.385 & 0.253 & 0.242 & 0.235 \\
\hline 09 & Midwest & 1.841 & 1.891 & 1.928 & 0.209 & 0.200 & 0.193 \\
\hline 10 & Midwest & 3.046 & 3.198 & 3.289 & 0.553 & 0.525 & 0.506 \\
\hline
\end{tabular}

Notes: SPARROW = Spatially Referenced Regression On Watershed-attributes. 
nificant variable in the Southeast model; however, cover crops also contribute to reducing $\mathrm{P}$ loads. The coefficient for cover crops in the Midwest $\mathrm{P}$ model indicated that cover crops and reduced tillage practices result in decreased $\mathrm{P}$ loss to streams. This agrees with findings by Wang et al. (2015) and Sharpley et al. (2000).

Results from SPARROW simulations with varying BMP intensity indicate that both cover crops and reduced tillage practices reduced $\mathrm{P}$ losses from agricultural areas, and reduced tillage practices increased $\mathrm{N}$ losses. In all three regional $\mathrm{P}$ models, BMPs (both cover crops and reduced tillage) reduced $\mathrm{P}$ export from the watersheds. Both of these BMPs are designed to reduce soil erosion and therefore suggest that erosion control has a significant effect on the fraction of instream $\mathrm{P}$ loads associated with soil loss. Although particulate $\mathrm{P}$ comprises a major part of the $\mathrm{P}$ loads, reducing the dissolved fraction is also integral to reducing $\mathrm{P}$ losses. Nevertheless, the advantages of using soil conservation measures to reduce $\mathrm{P}$ losses as predicted in this study are consistent with findings from other studies (Stevens et al. 2009; Richardson and King 1995; Andraski et al. 1985). In the Northeast, the change in agricultural $\mathrm{P}$ load caused by the increase in BMPs was nearly twice what was predicted in the other regions. The larger effect of the BMPs may have been caused by a larger area of application rather than it being more effective in the Northeast, since the magnitude of the coefficient of the BMP was similar to that in the Midwest.

In mitigating the $\mathrm{P}$ loss from agricultural fields, careful design and implementation of conservation strategies must also account for dissolved forms of P. Studies conducted by many investigators have concluded that runoff and subsurface flow are major transport vectors of dissolved P (Heathwaite and Dils 2000; Andraski et al. 1985; Sharpley et al. 1987). Tools for assessing the potential for P loss from agricultural areas are critical to the development of effective BMPs (e.g., P-index [Sharpley et al. 2001]) because they help to identify the processes that pose the greatest risk to water quality. In runoff from agricultural fields where $\mathrm{P}$ fertilizers have been applied, many studies have demonstrated the increased risk of P loss (Duncan et al 2017; Vadas et al. 2008; Nash et al. 2004). Accumulation of $\mathrm{P}$ from historic fertilizer and manure use form pools of legacy $\mathrm{P}$ that further the risk to water quality. In a recent review of $\mathrm{P}$ dynamics in the Northeast, Kleinman et al. (2019) describe legacy $\mathrm{P}$ as

\section{Figure 4}

Regional Spatially Referenced Regression On Watershed-attributes (SPARROW) model results for phosphorus (P) loads from applied increases and decreases of best management practice (BMP) implementation. (a) $\mathrm{P}$ load percentages of change from agricultural sources with a $50 \%$ increase in BMP intensity; (b) P load percentages of change from all nutrient sources with a $50 \%$ increase in BMP intensity; (c) P load percentages of change from agricultural sources with a $50 \%$ decrease in BMP intensity; (d) P load percentages of change from all nutrient sources with a $50 \%$ decrease in BMP intensity. Shaded regions of the maps represent HUC2 basins (Seaber et al. 1987) used in this study.

(a)

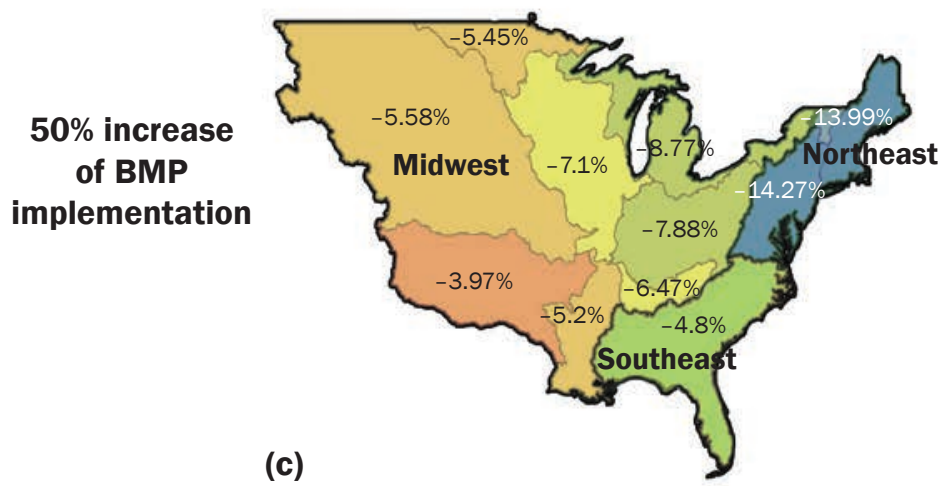

(c)

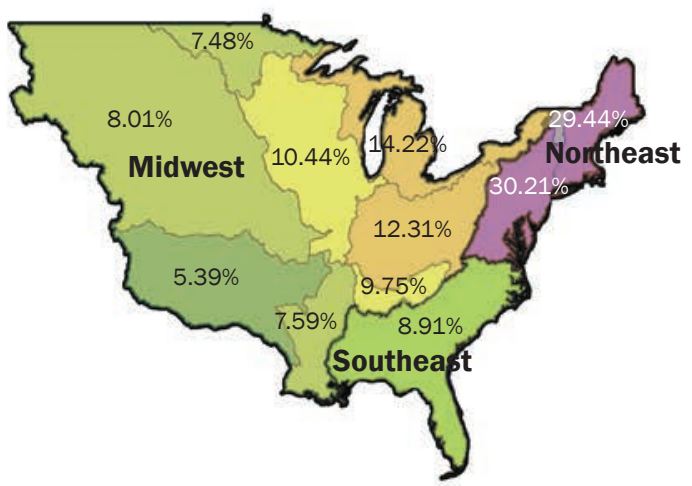

(b)

Overall load change
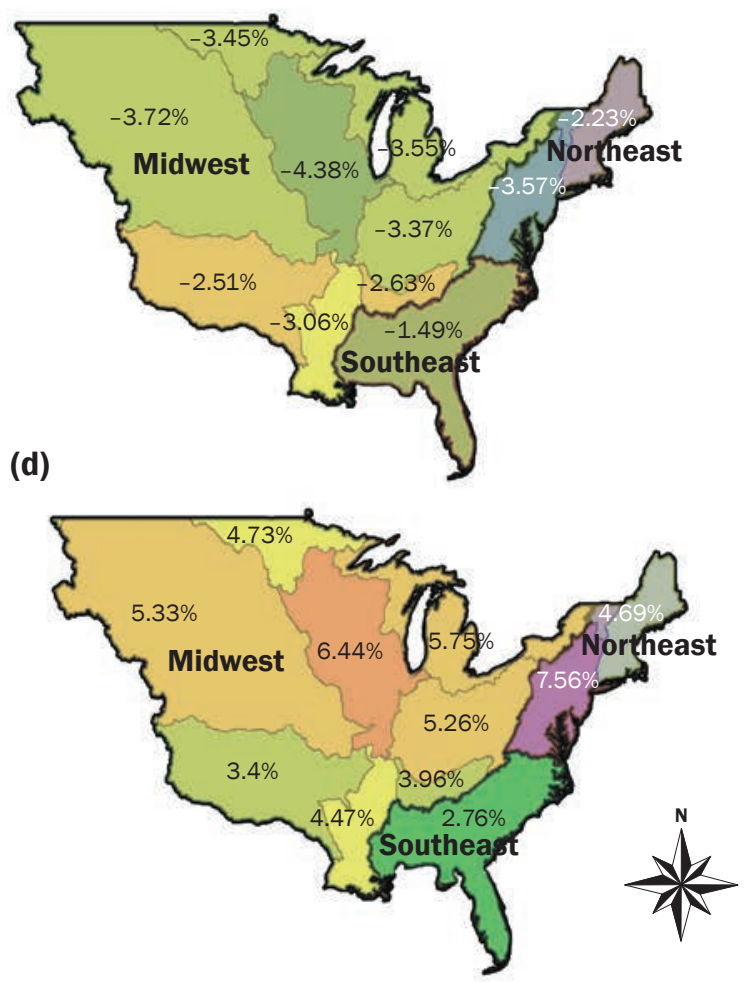
generally being more labile than $\mathrm{P}$ associated with the soil because it can be easily dissolved. Cover crops and reduced tillage that control erosion to mitigate $\mathrm{P}$ losses may be rendered less effective if a substantial part of $\mathrm{P}$ losses from an area are from legacy P. Furthermore, we note that changes in hydrology play a critical role in P transport (Kleinman et al. 2011) and water management such as tile-drainage can change the impact of BMPs by altering preferential flow pathways. The Midwest model accounted for some degree of water management impact with the inclusion of a tile-drainage variable. Future studies could consider other similar water management activities such as irrigation and open channel drainage in the Southeast.

Over the past decade, cover crops have gained support as an effective management strategy to reduce nutrient and soil losses from agricultural fields (Arbuckle and Roesch-McNally 2015; Hively et al. 2009; Sainju and Singh 1997). Historically, the use of cover crops lagged behind the use of other conservation practices, e.g., reduced tillage, due to economic drivers and other considerations such as managing seeding and cover crop termination (Roesch-McNally et al. 2018; O'Connell et al. 2015). The results of this study provide evidence that the gains achieved with cover crop adoption can play an important role in mediating $\mathrm{P}$ and $\mathrm{N}$ loss to streams, which is in agreement with the findings of other investigators (Shelton et al. 2018; Kladivko et al. 2014; Sharpley et al. 1991). A survey of farmers across the United States (2012 Agricultural Census) showed conservation tillage and no-till were adopted on $90 \%$ more land than cover crops as of 2012 (USDA NASS 2014). However, based on the 2017 Agricultural Census (USDA NASS 2019), the use of cover crops has outpaced conservation tillage and no-till by 41\%. Although the 2007 Agricultural Census reported cover crop area as a lumped value, which included idle cropland and soil-improvement land, that area also increased over the survey period (USDA NASS 2009). Growing adoption of cover crops can largely be attributed to scientific and technological advances as well as advances that have come from efforts to improve farmers' understanding of the advantages and disadvantages associated with adopting cover crops: improved understanding, for example, that cover crops are more efficient at reducing $\mathrm{N}$ losses than conservation tillage in some areas, or that interactions between different conservation practices must be accounted for in nutrient management plans (Dunn et al. 2016; Arbuckle and Roesch-McNally 2015).

Quantifying Regional Effects of Best Management Practices on Nutrient Loading to Lake Erie. In 2011, the International Joint Commission (IJC) identified nutrient contamination as a leading factor in the development of nearshore eutrophication and the reemergence of harmful algal blooms (HABs) in Western Lake Erie (in the Midwest SPARROW model) (Reutter et al. 2011). Many studies have identified $P$ as the limiting nutrient in Lake Erie (Wilhelm et al. 2003; DeBruyn et al. 2004; Guildford et al. 2005) and a key driver of lake eutrophication (Vollenweider 1968). Eutrophication in Lake Erie in the past two to three decades has raised concerns about the occurrence of HABs and how best to forecast their occurrence and size using estimates of $\mathrm{P}$ loading (Obenour et al. 2014). The 1972 Great Lakes Water Quality Agreement was implemented with the target of reducing point source $\mathrm{P}$ loading by 50\% by 1982 (IJC 1986). In 2012, the IJC updated the $\mathrm{P}$ target to a $40 \%$ reduction (186 t) from 2008 levels (IJC 2012).

In the BMP simulation results presented in this paper for the Midwest, increasing BMP intensity increased $\mathrm{N}$ loads and decreased $\mathrm{P}$ loads delivered to Western Lake Erie. Specifically, if the amount of no-till in the Midwest $\mathrm{N}$ model were to increase by $50 \%$, an additional $2.62 \times 10^{6} \mathrm{~kg}$ of $\mathrm{N}$ could be delivered to Western Lake Erie, which represents a 3.61\% increase (table 4).Adding 50\% more cover crops in the Midwest $\mathrm{P}$ model reduces the amount of $\mathrm{P}$ delivered to the lake by $1.90 \times 10^{5} \mathrm{~kg}$, which represents a $6.00 \%$ reduction (table 4). These results corroborate the conclusions from other modeling approaches (Scavia et al. 2016) that although some reduction in agricultural $\mathrm{P}$ and $\mathrm{N}$ loads are achievable with conservation BMPs, like the ones tested in this model, these measures alone will not be successful in reaching the nutrient targets to restore the impacted ecosystems. In 2006, 94\% of the agricultural land in the Great Lakes had some form of conservation or nutrient-management practice in place to reduce nutrient losses (USDA NRCS 2011). In an assessment of nutrient control scenarios using multiple models (Soil and Water Assessment Tool [SWAT] [Arnold et al.2012] and SPARROW), the most effective management scenarios for the reduction of nutrient loads included similar BMPs to those tested in this study (the ones tested in this study are vegetative BMPs), land use conversion, and nutrient management (Scavia et al. 2016).

The USDA-CEAP (USDA NRCS 2011) conducted a model-based regional assessment of BMPs for the baseline period from 2003 to 2006 in the Lake Erie Basin. The authors of the study concluded that conservation practices accounted for $\mathrm{N}$ and $\mathrm{P}$ load reductions of $17 \%$ and $18 \%$, respectively, relative to not having implemented any conservation practices. When the authors simulated $\mathrm{N}$ and $\mathrm{P}$ delivery to rivers and streams as a result of increasing conservation treatment to critically undertreated areas $\left(1.15 \times 10^{4}\right.$ $\left.\mathrm{km}^{2}\right)$ and to all under-treated areas $(3.20 \times$ $10^{4} \mathrm{~km}^{2}$ ), $\mathrm{N}$ loads were reduced by an additional $4 \%$ to $14 \%$, respectively, and $\mathrm{P}$ loads by an additional $3 \%$ to $20 \%$, respectively (table $4)$. Because of differences in the methodologies used in the CEAP study and the study that is being presented here, comparisons of the two studies are only qualitative. For $\mathrm{P}$, this study and the CEAP study agree that increasing the implementation of BMPs has a positive effect on water quality, albeit falling short of the proposed target reduction, but the studies do not agree on effects for $\mathrm{N}$. We speculate that BMPs do not have a similar effect on $\mathrm{N}$ loads in the Midwest in large part due to the characterization of the BMPs on the landscape. The Midwest model domain was the largest of the three models used in this study and with respect to BMPs may have the most spatial variability in BMP implementation. A regionalized approach to the characterization of BMPs in the Midwest may present opportunities for improvements in the specification of BMPs in the model. The characterization of BMPs in the SPARROW models are the best representation relative to the available data used to construct the models, but they (along with other similar regional water quality models) are not able to predict the influence of all BMPs on the landscape.

Quantifying Regional Effects of Best Management Practices on Nutrient Loading to the Chesapeake Bay. In the Chesapeake Bay watershed (in the Northeast SPARROW model), the Total Maximum Daily Load (TMDL) established in 2010 targeted 25\% and $24 \%$ reductions in annual $\mathrm{N}$ and $\mathrm{P}$ loads, respectively (USEPA 2010). This equated to annual load limits of 84.3 million $\mathrm{kg} \mathrm{y}^{-1}$ for 
$\mathrm{N}$ and 5.69 million $\mathrm{kg} \mathrm{y}^{-1}$ for $\mathrm{P}$ (Linker et al. 2013). Based on the results of this study, increased intensity of BMPs in the Northeast increases $\mathrm{N}$ loads and decreases $\mathrm{P}$ loads. If the amount of BMPs in the Northeast $\mathrm{N}$ model were to increase by $50 \%$, the Chesapeake Bay could receive an additional $1.13 \times 10^{6} \mathrm{~kg}$ of $\mathrm{N}$, which represents an increase of approximately $0.91 \%$ (table 4). The Atlantic Ocean could receive an additional $1.63 \times 10^{6} \mathrm{~kg}$ of $\mathrm{N}$ from the Northeast United States, which represents an increase of $0.56 \%$ (table 4 ). For the Northeast P model, the P load delivered to the Chesapeake Bay could decrease by $5.06 \times 10^{5} \mathrm{~kg}$, a $6.29 \%$ reduction, as a result of a 50\% increase in BMPs (table 4). The P load delivered to the Atlantic Ocean could decrease by $8.10 \times 10^{5} \mathrm{~kg}$, which represents a $3.42 \%$ reduction (table 4 ).

We compare the results presented in this study with those from a CEAP regional watershed study of the Chesapeake Bay (USDA NRCS 2013). From 2003 to 2011, the percentage of agricultural area in the Chesapeake Bay watershed with conservation tillage increased $23 \%$, no-till by $16 \%$, and cover crops by $40 \%$ (USDA NRCS 2013). In the same study, SWAT model simulations were used to assess the impact of conservation practices on $\mathrm{N}$ and $\mathrm{P}$ loads delivered to the Chesapeake Bay. The study concluded that conservation practices in 2011 reduced $\mathrm{N}$ and $\mathrm{P}$ loading by $17 \%$ and $21 \%$ respectively, when compared to conditions where no conservation practices were implemented. The authors also compared N and $\mathrm{P}$ loads delivered to the bay for the level of conservation implementation during the baseline years 2003 to 2006 with conditions in 2011. Relative to the baseline conditions, $\mathrm{N}$ and $\mathrm{P}$ loads decreased by $6 \%$ and $5 \%$, respectively (table 4). The SPARROW models in this study cannot be used to produce simulations of the no conservation practice scenario, for comparison with the SWAT model simulations, due to lack of robustness and reliability (described in the Materials and Methods section) of SPARROW predictions when simulations of the BMP variables approach zero. Qualitative comparison of the results from this study to the conditions in 2011 presented in the CEAP study is possible, however, and shows there are some points of general agreement. The studies agree that increasing the implementation of cover crops is an effective conservation practice for controlling $\mathrm{N}$ delivery to the Chesapeake Bay; however, the studies disagree on the effects of tillage on $\mathrm{N}$ delivery. The studies agree that increasing tillage con- servation practices reduces $\mathrm{P}$ delivery to the Chesapeake Bay. Differences in the methodologies between the two studies explain discrepancies in the magnitude and nature of the potential changes in the delivered loads that could come from more aggressive adoption of BMPs.

Results from the Northeast SPARROW models present a complicated set of circumstances to be navigated by managers because of the contrasting effects of cover crops and reduced tillage BMPs on $\mathrm{N}$ loads, and the contrasting effects of reduced tillage BMPs on $\mathrm{N}$ versus $\mathrm{P}$ loads. These contrasting effects would be consistent, however, with the adoption of more cover crops to mitigate $\mathrm{N}$, and additional reduced tillage to mitigate $\mathrm{P}$ loads. The results of both studies demonstrate that the potential changes in $\mathrm{N}$ and $\mathrm{P}$ delivery to the Chesapeake Bay fall short of the reduction targets outlined by the USEPA (2010) based on the amount of cropland area where these conservation practices could be implemented. The challenges associated with controlling nutrient pollution in the Chesapeake Bay is further exacerbated by fluxes of nonagricultural nutrient sources. The results of this study suggest that limiting only agricultural nutrient sources have little influence on the overall nutrient loads

\section{Table 4}

Comparison of nutrient load reductions for major drainages from the Spatially Referenced Regression On Watershed-attributes (SPARROW) model simulations where the fraction of best management practices (BMPs) on agricultural land is increased by $50 \%$ relative to conditions in 2012 and reductions from the Conservation Effects Assessment Program (CEAP) watershed studies. CEAP studies examine BMP effects on nutrient loads between 2003 to 2006 and 2011, and BMP effects from increasing BMP intensity for undertreated agricultural lands.

\begin{tabular}{|c|c|c|c|c|}
\hline \multirow[b]{2}{*}{ Receiving waterbody } & \multirow[b]{2}{*}{ Model } & \multirow[b]{2}{*}{$\begin{array}{l}\text { Percentage of ag } \\
\text { land with BMPs }(\%)^{*}\end{array}$} & \multirow{2}{*}{$\begin{array}{l}\text { This study } \\
\text { Load change (\%) }\end{array}$} & \multirow{2}{*}{$\begin{array}{l}\text { Other studies } \\
\text { Load change (\%) }\end{array}$} \\
\hline & & & & \\
\hline Chesapeake Bay & $\mathrm{N}$ & 60 & 0.91 & $-6 \dagger$ \\
\hline Chesapeak Bay & $\mathrm{P}$ & 48 & -6.29 & $-5 \dagger$ \\
\hline Atlantic Ocean (Northeast) & $\mathrm{N}$ & 60 & 0.56 & - \\
\hline Atlantic Ocean (Northeast) & $\mathrm{P}$ & 48 & -3.42 & - \\
\hline Gulf of Mexico (Missississippi-Atchafalaya River Basin) & $\mathrm{N}$ & 42 & 2.73 & $-11 \S$ \\
\hline Gulf of Mexico (Missississippi-Atchafalaya River Basin) & $\mathrm{P}$ & 2.8 & -3.58 & $-16 \S$ \\
\hline Gulf of Mexico (Southeast Gulf Coast) & $\mathrm{N}$ & 9.4 & -0.27 & $-11 \S$ \\
\hline Gulf of Mexico (Southeast Gulf Coast) & $\mathrm{P}$ & 45 & -3.22 & $-16 \S$ \\
\hline
\end{tabular}

*Percentage of agricultural land with BMPs as characterized in regional SPARROW models (Robertson and Saad 2019; Ator 2019; Hoos and Roland 2019).

†CEAP; USDA Natural Resources Conservation Service (2013).

¥USDA National Resources Conservation Service (2011).

§USDA Natural Resources Conservation Service (2014). 
delivered to the Chesapeake Bay. In the Chesapeake Bay, fluxes from wastewater treatment, urban runoff, and septic systems contribute the largest fraction of $\mathrm{N}$ and $\mathrm{P}$ to the bay (Ator 2019). Therefore, achieving nutrient targets will require aggressive actions, which target both agricultural and nonagricultural sources of nutrients.

Quantifying Regional Effects of Best Management Practices on Nutrient Loading to the Gulf of Mexico. The Gulf Hypoxia Taskforce was created to address water quality issues in the Gulf of Mexico and throughout its watershed. The taskforce identified agricultural nutrient sources as a significant driver in the size of the hypoxic zone in the Gulf of Mexico. The use of agricultural BMPs was identified as an integral part of the strategy to reduce nutrient inputs to the Gulf by $30 \%$ of historic levels (Mississippi River/Gulf of Mexico Watershed Nutrient Task Force 2001). In their 2017 report (USEPA 2018), the taskforce set a goal of a $20 \%$ reduction of nutrients in the Gulf by 2025 and full realization of the nutrient reduction target by 2035. In this study $\mathrm{N}$ and P loads delivered to the Gulf of Mexico were simulated by the Midwest and Southeast models. The Midwest model accounted for $\mathrm{N}$ and $\mathrm{P}$ inputs from the Mississippi-Atchafalaya River Basin and the Southeast model accounted for inputs along the Gulf Coast. As stated in the previous section, increasing BMPs by $50 \%$ in the Midwest $\mathrm{N}$ model increased loads, and in the P model loads decreased. Using the Midwest models for the Mississippi-Atchafalaya River watershed, increasing BMPs $50 \%$ could result in the delivery of an additional $42.0 \times 10^{6} \mathrm{~kg}$ of $\mathrm{N}$ to the Gulf, which is a $2.73 \%$ increase (table 4), and a decrease of $6.8 \times 10^{6} \mathrm{~kg}$ of $\mathrm{P}$, which is a $3.58 \%$ decrease (table 4 ). Using the Southeast models for the direct drainages along the Gulf Coast, increasing BMPs 50\% could result in a $4.73 \times 10^{4} \mathrm{~kg}$ decrease of $\mathrm{N}$ delivered to the Gulf, which represents a $0.27 \%$ decrease (table 4 ). The amount of $\mathrm{P}$ delivered to the Gulf from the direct drainages could decrease by $7.62 \times 10^{4} \mathrm{~kg}$, which represents a $3.22 \%$ decrease (table 4 ). If the model results for the two regions (Midwest and Southeast) are combined, the amount of $\mathrm{N}$ delivered to the Gulf could increase by $2.46 \%$ and the amount of $\mathrm{P}$ delivered to the Gulf could decrease by $6.8 \%$.

In an earlier study of BMPs in the Upper Mississippi River basin, N reductions attributed to BMPs ranged from 5\% to $34 \%$, and $\mathrm{P}$ reductions ranged from $1 \%$ to $10 \%$ (Garcia et al. 2016). According to a CEAP study that used SWAT models to estimate load changes from increased BMP intensity between 2003 to 2006 and 2011, the $\mathrm{N}$ load delivered to the Gulf of Mexico should have decreased by $11 \%$ and the $\mathrm{P}$ load should have decreased by $16 \%$ (table 4) (USDA NRCS 2014). As noted in discussions of the other CEAP studies earlier in this section, differences in estimates of the potential load reductions between the CEAP studies and this study are expected due to different frameworks and time periods, and more detailed information describing BMP adoption rates and a wider variety of BMPs included in the CEAP studies. Nevertheless, these comparisons are meaningful because they provide additional insights with respect to the trajectory of conservation activities toward reaching nutrient reduction targets. The results of this study and the other studies described in this section demonstrate the complexity in assessing the active roles of BMPs in the transport of $\mathrm{N}$ and $\mathrm{P}$ at large spatial scales, interactions between multiple BMPs, and the net effects of upstream practices on $\mathrm{N}$ and $\mathrm{P}$ delivery to major drainages. The consensus of all the studies is that additional actions are needed, beyond the conservation practices considered here, to reach nutrient targets in all regions. These actions could include nutrient management plans, structural BMPs, more aggressive (than $50 \%$ ) increases in cover crops and tillage practices, or reducing fertilizer use. In addition to expanding and improving current conservation practices and technologies, it will also be important to understand the economic implications of this growth. Because of the changing global economy, increasing urbanization, and growing industrialization in emerging economies, aligning the goals of nutrient management within the context of these societal and economic factors will only become more important. The impacts of climate change on nutrient management will also be an important consideration in the management of water resources and the development of nutrient targets. Studies have demonstrated the potential for increasing nutrient availability (Feuchtmayr et al. 2009; Frey et al. 2007; Jones 2005) resulting from increasing global temperatures. Extreme storm events driven by climate variability are projected to increase runoff (Wang et al. 2018; Rotz et al. 2016) containing larger nutrient concentrations. The variable nature of climate change will not influence water quality uniformly across a range of spatial and temporal scales. Nevertheless, the findings of these studies emphasize the importance of more aggressive implementation of effective strategies to mitigate negative environmental and economic outcomes in the future.

Limitations in Best Management Practice Analysis. In practice, implementation of conservation practices typically involves adopting multiple BMPs simultaneously to increase the potential to reduce nutrient losses (Wade et al. 2015). This study focuses on a subset of vegetative practices, which is a simplification of what was actually implemented in the catchment areas. Improving our understanding of BMPs and our assessments of their effectiveness should consider all conservation practices used in developing regional-scale nutrient reduction targets to reduce nutrient pollution. Accounting for input reduction practices that are part of nutrient management programs is difficult because these types of conservation actions do not typically change land cover as is the case with vegetative BMPs, rather they attempt to reduce nutrient losses by reducing the mass of nutrients applied to the surface of soils. Meeting the goals of nutrient management plans is most often the responsibility of farmers who must determine the most feasible practices to implement on their farms. Accounting for each individual farm-scale management practice is a challenge for largescale regional models because the availability of these data is based on individual reporting requirements, which may vary. Since they do not trigger large-scale changes, the effects of local-scale management actions are not captured unless it is assumed that their influence is inherent to the observations used in model calibration. Therefore, many largescale models, including SPARROW, assume that source data inputs include the effects of large-scale nutrient management practices, which include fertilizer application reduction plans.

The present analysis is also limited in the representation of more dynamic practices and the contributions of legacy nutrient masses or contributions from sediment bound $\mathrm{N}$ and $\mathrm{P}$ that is trapped in soils, stored in stream channels, or dissolved in groundwater. The nutrient source data used in the SPARROW models represent a specific base year. Because of the static nature of the SPARROW mod- 
els used in the study, simulating transient effects of BMPs was outside of the scope of this study. As a result, it should not be assumed that the models represent equilibrium conditions in which the full effects of source control BMPs or structural BMPs are realized. Assessing the lag between the implementation of BMPs and temporal changes in nutrient loads is best done using dynamic constructs of the SPARROW model or by using multiple static SPARROW models representing different points in time (Ator et al. 2019).

This analysis of the regional effects of BMPs is a novel application of the SPARROW model. Assessments of this type may be valuable to state and federal agencies in the development of effective nutrient management strategies. In subsequent BMP assessments using the SPARROW model, increasing the quantity and quality of BMP data would help to improve future models and their usefulness as decision support tools. Having an accurate accounting of catchment areas where specific vegetative or structural BMPs are adopted is an important example for several reasons, such as assessing the return on investment in programs that incentivize BMP adoption. Facilitated by advancements in remote sensing, the ability to accurately quantify BMPs has greatly improved, but opportunities remain to further advance the quality and quantity of BMP data. Improving the resolution of BMP data beyond the county level data used in this study represents a significant advancement. County level BMP data are very coarse and can introduce additional model uncertainty when these data are extrapolated to the catchment level. Apportionment of the amount of BMP area within a catchment relative to county totals is complicated because catchments generally do not adhere to political boundaries and distributing BMP area to catchments by some weighting methodology based on county area may oversimplify and homogenize the distribution of BMPs on the landscape, which potentially dilutes the effects of BMPs with smaller footprints. This represents an important limitation of the models used in this study, but currently this approach represents the best viable option to conduct these types of assessments with SPARROW.

\section{Summary and Conclusions}

The effects of BMPs on nutrient loads were simulated using published regional SPARROW models. Altering the intensity of BMPs by $50 \%$ had modest effects (generally between $4 \%$ and $15 \%$ ) on the agricultural component of $\mathrm{N}$ and $\mathrm{P}$ loads for Midwest, Northeast, and Southeast regions of the United States, but had small effect (generally less than $4 \%$ ) on overall $\mathrm{N}$ and $\mathrm{P}$ loads and instream concentrations. In most cases increasing the intensity of BMPs reduces $N$ and P losses to streams; the exception is for $\mathrm{N}$ in the Northeast and Midwest regions, for which the net effect of increasing the area using reduced tillage practices increased instream $\mathrm{N}$ loads. The implementation of cover crops and tillage practices reduced $\mathrm{P}$ loads. Specification testing of the regional models resulted in a range of interpretations for BMP variables, but most importantly verified that the BMPs were adequately represented in the models. In some cases (the Midwest $\mathrm{N}$ model and Southeast $\mathrm{P}$ model), however, the effects of a specific BMP were indistinguishable from the overall effect of other BMPs in the model area. Because of the low spatial resolution of the conservation data used, these BMP effects are more accurately interpreted as being representative of the overall effects of all of the BMPs used in the area. The models indicated that the most successful load reductions through use of BMPs resulted from using multiple practices. Higher resolution data could improve the model's ability to parse the effects of particular BMPs and account for additional nutrient transport processes that were not explored in this study.

\section{Supplemental Material}

Supplementary material for this article is available in the online journal at https://doi.org/10.2489/jswc.2022.00162.

\section{Acknowledgements}

Support of the US Geological Survey (USGS) National Water Quality Program, thoughtful comments, and suggestions by Anne Hoos (USGS Emeritus), and two anonymous peers facilitated and improved this paper. Any use of trade, firm, or product names is for descriptive purposes only and does not imply endorsement by the US Government.

\section{References}

Alberts, E.E., and R.G. Spomer. 1985. Dissolved nitrogen and phosphorus in runoff from watersheds in conservation and conventional tillage. Journal of Soil and Water Conservation 40(1):153-157.
Andraski, B.J., D.H. Mueller, and T.C. Daniel. 1985. Phosphorus losses in runoff as affected by tillage. Soil Science Society of America Journal 49(6):1523-1527. https://doi.org/10.2136/sssaj1985.0361599500490006 0038x.

Arbuckle, J.G., and G. Roesch-McNally. 2015. Cover crop adoption in Iowa: The role of perceived practice characteristics. Journal of Soil and Water Conservation 70(6):418-429. https://doi.org/10.2489/jswc.70.6.418. Arnold, J.G., D.N. Moriasi, P.W. Gassman, K.C. Abbaspour, M.J.White, R. Srinivasan, C. Santhi, R.D. Harmel, A.Van Griensven, M.W. Van Liew, N. Kannan, and M.K. Jha. 2012. SWAT-Model use, calibration, and validation. Transactions of the ASABE 55(4):1491-1508. doi:10.13031/2013.42256.

Ator, S.W. 2019. Spatially referenced models of streamflow and nitrogen, phosphorus, and suspended-sediment loads in streams of the northeastern United States. U.S. Geological Survey Scientific Investigations Report, 2019-5118. Reston, VA: USGS. https://doi. org/10.3133/sir20195118.

Ator, S.W., A.M. García, G.E. Schwarz, J.D. Blomquist, and A.J. Sekellick. 2019. Toward explaining nitrogen and phosphorus trends in Chesapeake Bay tributaries, 1992-2012. Journal of the American Water Resources Association 55(5):1149-1168. https://doi. org/10.1111/1752-1688.12756.

Baker, D.B. 1993. The Lake Erie agroecosystem program: Water quality assessments. Agriculture, Ecosystems \& Environment 46(1-4):197-215. https://doi. org/10.1016/0167-8809(93)90024-J.

Becker, J.C. 2002. Promoting agricultural development through land use planning limits. Real Property, Probate and Trust Journal 36(4):619-671.

Bricker, S., B. Longstaff, W. Dennison, A. Jones, K. Boicourt, C. Wicks, and J. Woerner. 2007. Effects of nutrient enrichment in the nation's estuaries: A decade of change. NOAA Coastal Ocean Program Decision Analysis Series No. 26. Silver Spring, MD: National Center for Coastal Ocean Science.

Cao, P., C. Lu, and Z. Yu. 2018. Historical nitrogen fertilizer use in agricultural ecosystems of the contiguous United States during 1850-2015: Application rate, timing, and fertilizer types. Earth System Science Data 10(2):969984. https://doi.org/10.5194/essd-2017-132.

Carpenter, S.R., N.F. Caraco, D.L. Correll, R.W. Howarth, A.N. Sharpley, and V.H. Smith. 1998. Nonpoint pollution of surface waters with phosphorus and nitrogen. Ecological Applications 8(3):559-568. https:// doi.org/10.1890/1051-0761(1998)008[0559:NPOSW $\mathrm{W}] 2.0 . \mathrm{CO} ; 2$.

Congress.gov. 2002. H.R.2646 - 107th Congress (20012002): Farm Security and Rural Investment Act of 2002. May 13, 2002. https://www.congress.gov/ bill/107th-congress/house-bill/2646.

Cox, C. 2007. US Agriculture Conservation Policy and Programs: History, Trends, and Implications. Chapter 
III-2. In US Agricultural Policy and the 2007 Farm Bill. Stanford, CA: Woods Institute for the Environment, Stanford University.

Daryanto, S., L. Wang, and P.A. Jacinthe. 2017. Impacts of no-tillage management on nitrate loss from corn, soybean and wheat cultivation: A meta-analysis. Scientific Reports 7(1):1-9. https://doi.org/10.1038/ s41598-017-12383-7.

Davidson, E.A., M.B. David, J.N. Galloway, C.L. Goodale, R. Haeuber, J.A. Harrison, R.W. Howarth, D.B. Jaynes, R.R. Lowrance, B.T. Nolan, J.L. Peel, R.W. Pinder, E. Porter, C.S. Snyder, A.R. Townsend, and M.H. Ward. 2011. Excess nitrogen in the U.S. environment: Trends, risks, and solutions. Ecological Society of America. Issues in Ecology (15).

Davidson, R., and J.G. MacKinnon. 1993. Estimation and Inference in Econometrics. Oxford, UK: Oxford University Press Catalogue, Oxford University Press.

DeBruyn, J.M., J.A. Leigh-Bell, R.L. McKay, R.A. Bourbonniere, and S.W. Wilhelm. 2004. Microbial distributions and the impact of phosphorus on bacterial activity in Lake Erie. Journal of Great Lakes Research 30(1):166-183.

Diaz, R.J., and R. Rosenberg. 2008. Spreading dead zones and consequences for marine ecosystems. Science 321(5891):926-929. https://doi.org/10.1126/ science. 1156401.

Duncan, E.W., K.W. King, M.R. Williams, G. LaBarge, L.A. Pease, D.R. Smith, and N.R. Fausey. 2017. Linking soil phosphorus to dissolved phosphorus losses in the midwest. Agricultural \& Environmental Letters 2(1):170004. https://doi.org/10.2134/ael2017.02.0004.

Dunn, M., J.D. Ulrich-Schad, L.S. Prokopy, R.L. Myers, C.R. Watts, and K. Scanlon. 2016. Perceptions and use of cover crops among early adopters: Findings from a national survey. Journal of Soil and Water Conservation 71(1):29-40. https://doi.org/10.2489/jswc.71.1.29.

Feuchtmayr, H., R. Moran, K. Hatton, L. Connor, T. Heyes, B. Moss, I. Harvey, and D. Atkinson. 2009. Global warming and eutrophication: Effects on water chemistry and autotrophic communities in experimental hypertrophic shallow lake mesocosms. Journal of Applied Ecology 46(3):713-723. https://doi. org/10.1111/j.1365-2664.2009.01644.x.

Forster, D.L., T.J. Logan, S.M.Yaksich, and J.R. Adams. 1985 An accelerated implementation program for reducing the diffuse-source phosphorus load to Lake Erie. Journal of Soil and Water Conservation 40(1):136-141.

Frey, K.E., J.W. McClelland, R.M. Holmes, and L.C. Smith. 2007. Impacts of climate warming and permafrost thaw on the riverine transport of nitrogen and phosphorus to the Kara Sea. Journal of Geophysical Research: Biogeosciences 112(G4). https://doi. org/10.1029/2006JG000369.

García, A.M., R.B. Alexander, J.G. Arnold, L. Norfleet, M.J. White, D.M. Robertson, and G.E. Schwarz. 2016. Regional effects of agricultural conservation practices on nutrient transport in the Upper Mississippi River Basin. Environmental Science and Technology 50(13):69917000. https://doi.org/10.1021/acs.est.5b03543.

Golmohammadi, G., R.P. Rudra, S.O. Prasher, A. Madani, P.K. Goel, and K. Mohammadi. 2016. Modeling the impacts of tillage practices on water table depth, drain outflow and nitrogen losses using DRAINMOD. Computers and Electronics in Agriculture 124:73-83. https://doi.org/10.1016/j.compag.2016.03.031.

Guildford, S.J., R.E. Hecky, R.E. Smith, W.D. Taylor, M.N Charlton, L. Barlow-Busch, and R.L. North. 2005 Phytoplankton nutrient status in Lake Erie in 1997. Journal of Great Lakes Research 31:72-88.

Hanrahan, B.R., J.L. Tank, S.F. Christopher, U.H. Mahl, M.T. Trentman, and T.V. Royer. 2018. Winter cover crops reduce nitrate loss in an agricultural watershed in the central U.S. Agriculture, Ecosystems \& Environment 265:513-523. https://doi.org/10.1016/j. agee.2018.07.004.

Heathwaite, A.L., and R.M. Dils. 2000. Characterising phosphorus loss in surface and subsurface hydrological pathways. Science of the Total Environment 251:523538. https://doi.org/10.1016/S0048-9697(00)00393-4.

Hively, W.D., M. Lang, G.W. McCarty, J. Keppler, A. Sadeghi, and L.L. McConnell. 2009. Using satellite remote sensing to estimate winter cover crop nutrient uptake efficiency. Journal of Soil and Water Conservation 64(5):303-313. https://doi.org/10.2489/jswc.64.5.303.

Homer, C., J. Dewitz, L. Yang, S. Jin, P. Danielson, G. Xian, J. Coulston, N. Herold, J. Wickham, and K. Megown. 2015. Completion of the 2011 National Land Cover Database for the conterminous United States-Representing a decade of land cover change information. Photogrammetric Engineering \& Remote Sensing 81(5):345-354.

Hoos, A.B., and V.L. Roland II. 2019. Spatially referenced models of streamflow and nitrogen, phosphorus, and suspended-sediment loads in the southeastern United States. US Geological Survey Scientific Investigations Report, 2019-5135, Reston, VA: USGS. https://doi. org/10.3133/sir20195135.

IJC (International Joint Commission). 2012. Great Lakes Water Quality Agreement 2012, Between the United States of America and Canada. Windsor, Ontario: International Joint Commission.

IJC. 1986. Third biennial report under the Great Lakes Water Quality Agreement of 1978. Windsor, Ontario: International Joint Commission.

Jamieson, A., C. Madramootoo, and P. Enright. 2003. Phosphorus losses in surface and subsurface runoff from a snowmelt event on an agricultural field in Quebec. Canadian Biosystems Engineering 45(1):1-1.7.

Jarvie, H.P., L.T. Johnson, A.N. Sharpley, D.R. Smith, D.B. Baker,T.W. Bruulsema, and R. Confesor. 2017. Increased soluble phosphorus loads to Lake Erie: Unintended consequences of conservation practices? Journal of
Environmental Quality 46(1):123-132. https://doi. org/10.2134/jeq2016.07.0248.

Jones, J.B. 2005. Nitrogen loss from watersheds of interior Alaska underlain with discontinuous permafrost. Geophysical Research Letters 32(2). https://doi. org/10.1029/2004GL021734.

Kemp, W., W. Boynton, J. Adolf, D. Boesch, W. Boicourt, G. Brush, J. Cornwell, T. Fisher, P. Glibert, J. Hagy, L. Harding, E. Houde, D. Kimmel, W. Miller, R. Newell, M. Roman, E. Smith, and J. Stevenson. 2005. Eutrophication of Chesapeake Bay: Historical trends and ecological interactions. Marine Ecology Progress Series 303:1-29. https://doi.org/10.3354/meps303001.

Kladivko, E.J., T.C. Kaspar, D.B. Jaynes, R.W. Malone, J. Singer, X.K. Morin, and T. Searchinger. 2014. Cover crops in the upper midwestern United States: Potential adoption and reduction of nitrate leaching in the Mississippi River Basin. Journal of Soil and Water Conservation 69(4):279-291. https://doi.org/10.2489/ jswc.69.4.279.

Kleinman, P.A., R.M. Fanelli, R.M. Hirsch, A.R. Buda, Z.M. Easton, L.A. Wainger, C. Brosch, M. Lowenfish, A.S. Collick, A. Shirmohammadi, K. Boomer, J.A. Hubbart, R.B. Bryant, and G.W. Shenk. 2019. Phosphorus and the Chesapeake Bay: Lingering issues and emerging concerns for agriculture. Journal of Environmental Quality 48(5):1191-1203. https://doi.org/10.2134/ jeq2019.03.0112.

Kleinman, P.J.A., A.N. Sharpley, R.W. McDowell, D.N. Flaten, A.R. Buda, L. Tao, L. Bergstrom, and Q. Zhu. 2011. Managing agricultural phosphorus for water quality protection: Principles for progress. Plant and Soil 349(1):169-182. https://doi.org/10.1007/ s11104-011-0832-9.

Lee, S., I.Y. Yeo, A.M. Sadeghi, G.W. McCarty, W.D. Hively, and M.W. Lang. 2016. Impacts of watershed characteristics and crop rotations on winter cover crop nitrate-nitrogen uptake capacity within agricultural watersheds in the Chesapeake Bay region. PLoS ONE 11(6):e0157637. https://doi.org/10.1371/journal. pone. 0157637 .

Linker, L.C., R.A. Batiuk, G.W. Shenk, and C.F. Cerco. 2013. Development of the Chesapeake Bay watershed total maximum daily load allocation. Journal of the American Water Resources Association 49(5):986-1006. https:// doi.org/10.1111/jawr.12105.

Michalak, A.M., E.J. Anderson, D. Beletsky, S. Boland, N.S. Bosch, T.B. Bridgeman, J.D. Chaffin, K. Cho, R. Confesor, I. Daloğlu, et al. 2013. Record-setting algal bloom in Lake Erie caused by agricultural and meteorological trends consistent with expected future conditions. Proceedings of the National Academy of Sciences 110(16):6448-6452.

Mississippi River/Gulf of Mexico Watershed Nutrient Task Force. 2001. Action plan for reducing, mitigating, and controlling hypoxia in the northern Gulf of Mexico. Washington, DC: US Environmental Protection Agency, 
Mississippi River/Gulf of Mexico Watershed Nutrient Task Force.

Nash, D., M. Hannah, L. Clemow, D. Halliwell, B. Webb, and D. Chapman. 2004. A field study of phosphorus mobilisation from commercial fertilisers. Soil Research 42(3):313-320.

Obenour, D.R., A.D. Gronewold, C.A. Stow, and D. Scavia. 2014. Using a Bayesian hierarchical model to improve Lake Erie cyanobacteria bloom forecasts. Water Resources Research 50(10):7847-7860. https://doi. org/10.1002/2014WR015616.

O'Connell, S., J.M. Grossman, G.D. Hoyt, W. Shi, S. Bowen, D.C. Marticorena, K.L. Fager, and N.G. Creamer. 2015. A survey of cover crop practices and perceptions of sustainable farmers in North Carolina and the surrounding region. Renewable Agriculture and Food Systems 30(6):550-562. https://www.jstor.org/ stable/26346612.

Rawlings, J.O., S.G. Pantula, and D.A. Dickey. 2001. Applied Regression Analysis: A Research Tool. New York: Springer Science \& Business Media.

Reutter, J.M., J. Ciborowski, J. DePinto, D. Bade, D. Baker, T.B. Bridgeman, D.A. Culver, S. Davis, E. Dayton, D. Kane, and R.W. Mullen. 2011. Lake Erie nutrient loading and harmful algal blooms: Research findings and management implications. Final Report of the Lake Erie Millennium Network Synthesis Team. Columbus, $\mathrm{OH}$ : The Ohio State University.

Richards, R.P., and D.B. Baker. 1997. Twenty years of change: The Lake Erie Agricultural Systems for Environmental Quality (LEASEQ) project. In Proceedings of the National Watershed Water Quality Symposium EPA/625/R-97/008. Washington, DC: USEPA.

Richardson, C.W., and K.W. King. 1995. Erosion and nutrient losses from zero tillage on a clay soil. Journal of Agricultural Engineering Research 61(2):81-86. https://doi.org/10.1006/jaer.1995.1034.

Robertson, D.M., and D.A. Saad. 2019. Spatially referenced models of streamflow and nitrogen, phosphorus, and suspended-sediment loads in streams of the midwestern United States. U.S. Geological Survey Scientific Investigations Report, 2019-5114. Reston, VA: USGS. https://doi.org/10.3133/sir20195114.

Robertson, D.M., and D.A. Saad. 2013. SPARROW models used to understand nutrient sources in the Mississippi/ Atchafalaya River Basin. Journal of Environmental Quality 42:1422-1440. https://doi.org/10.2134/ jeq2013.02.0066.

Roesch-McNally, G.E., A.D. Basche, J.G. Arbuckle, J.C. Tyndall, F.E. Miguez, T. Bowman, and R. Clay. 2018. The trouble with cover crops: Farmers' experiences with overcoming barriers to adoption. Renewable Agriculture and Food Systems 33(4):322-333. https:// doi.org/10.1017/S1742170517000096.

Roland II, V.L., A.M. Garcia, D.A. Saad, S.W. Ator, D.M. Robertson, and G.E. Schwarz. 2021. Nutrient Load Data used to Quantify Regional Effects of Agricultural
Best Management Practices: An application of the 2012 SPARROW models for the Midwest, Northeast, and Southeast United States: US Geological Survey data release. Reston, VA: USGS. https://doi.org/10.5066/ P9H2NDWU.

Rotz, C.A., R.H. Skinner, A.M. Stoner, and K. Hayhoe. 2016. Evaluating greenhouse gas mitigation and climate change adaptation in dairy production using farm simulation. Transactions of the ASABE 59(6):17711781. doi:10.13031/trans.59.11594.

Saad, D.A., D.M. Robertson, V.L. Roland II, A.M. Garcia, S.W. Ator, and G.E. Schwarz. 2021. SPARROW cover crop model coefficients, summary statistics, inputs and simulated total phosphorus loads in streams of the Midwest United States, 2012 Base Year: U.S. Geological Survey data release. Reston, VA: USGS. https://doi. org/10.5066/P9CLA42C.

Sainju, U.M., and B.P. Singh. 1997. Winter cover crops for sustainable agricultural systems: Influence on soil properties, water quality, and crop yields. HortScience 32(1):21-28.

Scavia, D., M. Kalcic, R.L. Muenich, N. Aloysius, J. Arnold, C. Boles, R. Confessor, J. De Pinto, M. Gildow, and J. Martin. 2016. Informing Lake Erie agriculture nutrient management via scenario evaluation. Ann Arbor, MI: University of Michigan.

Schwarz, G.E., A.B. Hoos, R.B. Alexander, and R.A. Smith. 2006. Section 3. The SPARROW Surface Water-Quality Model-Theory, application and user documentation. US Geological Survey Techniques and Methods, 6-B3. Reston,VA: USGS. https://pubs.er.usgs. gov/publication/tm6B3.

Schnepf, M., and C. Cox. 2006. Environmental Benefits of Conservation on Cropland:The Status of Our Knowledge. Ankeny, IA: Soil and Water Conservation Society.

Seaber, P.R., F.P. Kapinos, and G.L. Knapp. 1987. Hydrologic Unit maps: US Geological Survey Water-Supply Paper 2294. Reston, VA: USGS. http://water.usgs.gov/GIS/ huc.html.

Sekellick, A.J., O.H. Devereux, J.L.D. Keisman, J.S. Sweeney, and J.D. Blomquist. 2019. Spatial and temporal patterns of best management practice implementation in the Chesapeake Bay watershed 1985-2014. US Geological Survey Scientific Investigations Report 20185171. Reston, VA: USGS. https://doi.org/10.3133/ sir20185171.

Sharpley, A.N. 1987. Environmental impact of agricultural nitrogen and phosphorus use. Journal of Agricultural and Food Chemistry 35(5):812-817. https://doi. org/10.1021/jf00077a043.

Sharpley, A., B. Foy, and P. Withers. 2000. Practical and innovative measures for the control of agricultural phosphorus losses to water: An overview. Journal of Environmental Quality 29(1):1-9. https://doi. org/10.2134/jeq2000.00472425002900010001x.

Sharpley, A.N., R.W. McDowell, and P.J. Kleinman. 2001. Phosphorus loss from land to water: Integrating agricultural and environmental management. Plant and Soil 237(2):287-307.

Sharpley, A.N., S. Smith, and W. Hargrove. 1991. Effects of cover crops on surface water quality. In Cover Crops for Clean Water, 41-49. Ankeny, IA: Soil and Water Conservation Society.

Shelton, R.E., K.L. Jacobsen, and R.L. McCulley. 2018. Cover crops and fertilization alter nitrogen loss in organic and conventional conservation agriculture systems. Frontiers in Plant Science 8:2260. https://doi. org/10.3389/fpls.2017.02260.

Smith, D.R., W. Francesconi, S.J. Livingston, and C. Huang. 2015. Phosphorus losses from monitored fields with conservation practices in the Lake Erie Basin, USA. Ambio 44(2): 319-331.

Sprague, L.A., R.M. Mitchell, A.I. Pollard, and J.A. Falcone. 2019. Assessing water-quality changes in US rivers at multiple geographic scales using results from probabilistic and targeted monitoring. Environmental Monitoring and Assessment 191(6):1-12. https://doi. org/10.1007/s10661-019-7481-5.

Staver, K.W., and R.B. Brinsfield. 2001. Agriculture and water quality on the Maryland Eastern Shore:Where do we go from here? BioScience 51(10):859-868. https:// doi.org/10.1641/0006-3568(2001)051 [0859:AAWQO $\mathrm{T}] 2.0 . \mathrm{CO} ; 2$.

Stevens, C.J., J.N. Quinton, A.P. Bailey, C. Deasy, M. Silgram, and D.R. Jackson. 2009. The effects of minimal tillage, contour cultivation and in-field vegetative barriers on soil erosion and phosphorus loss. Soil and Tillage Research 106(1):145-151. https://doi.org/10.1016/j. still.2009.04.009

Tiessen, K.D., J.A. Elliott, J.Yarotski, D.A. Lobb, D.N. Flaten, and N.E. Glozier. 2010. Conventional and conservation tillage: Influence on seasonal runoff, sediment, and nutrient losses in the Canadian Prairies. Journal of Environmental Quality 39(3):964-980. https://doi. org/10.2134/jeq2009.0219.

Tomer, M.D., and M.A. Locke. 2011. The challenge of documenting water quality benefits of conservation practices: A review of USDA-ARS's Conservation Effects Assessment Project watershed studies. Water Science and Technology 64(1):300-310. 10.2166/ wst.2011.555.

Uribe, N., G. Corzo, M. Quintero, A. van Griensven, and D. Solomatine. 2018. Impact of conservation tillage on nitrogen and phosphorus runoff losses in a potato crop system in Fuquene watershed, Colombia. Agricultural Water Management 209:62-72. https:// doi.org/10.1016/j.agwat.2018.07.006.

USDA NASS (National Agricultural Statistics Service). 2009. 2007 Census of Agriculture. Washington, DC: USDA NASS.

USDA NASS. 2014. 2012 Census of Agriculture. Washington, DC: USDA NASS.

USDA NASS. 2019.2017 Census of Agriculture. Washington, DC: USDA NASS. 
USDA NRCS (Natural Resources Conservation Service) 2011. Assessment of the Effects of Conservation Practices on Cultivated Cropland in the Great Lakes Region. Washington, DC: USDA NRCS.

USDA NRCS. 2013. Impacts of Conservation Adoption on Cultivated Acres of Cropland in the Chesapeake Bay Region, 2003-06 to 2011. Washington, DC: USDA NRCS.

USDA NRCS. 2014. Assessment of the Effects of Conservation Practices on Cultivated Cropland in the South Atlantic Gulf Basin. Washington, DC: USDA NRCS.

USDA NRCS. 2015. USDA-NASS Cropland Data Layer. Washington, DC: USDA NRCS. https://gdg.sc.egov. usda.gov/GDGHome.aspx.

USDA NRCS. 2017. Conservation Practice Adoption on Cultivated Cropland Acres: Effect on Instream Nutrient and Sediment Dynamics and Delivery in Western Lake Erie Basin, 2003-06 and 2012. Washington, DC: USDA NRCS.

USEPA (Environmental Protection Agency). 2010. Chesapeake Bay TMDL. Washington, DC: USEPA.

USEPA. 2018. Mississippi/River/Gulf of Mexico Hypoxia Task Force. Washington, DC: USEPA. https://www.epa. gov/ms-htf.

Vadas, P.A., L.B. Owens, and A.N. Sharpley. 2008. An empirical model for dissolved phosphorus in runoff from surface-applied fertilizers. Agriculture, Ecosystems \& Environment 127(1-2):59-65. https://doi. org/10.1016/j.agee.2008.03.001.

Vitousek, P.M., J.D. Aber, R.W. Howarth, G.E. Likens, P.A Matson, D.W. Schindler, W.H. Schlesinger, and D.G. Tilman. 1997. Human alteration of the global nitrogen cycle: Sources and consequences. Ecological Applications 7(3):737-750. https://doi.org/10.1890/1051-0761(1997)007[0737:HAO TGN]2.0.CO;2.

Vollenweider, R.A. 1968. Scientific fundamentals of the eutrophication of lakes and flowing waters, with particular reference to phosphorus and nitrogen as factors in eutrophication. Paris: Organization for Economic Co-operation and Development Technical Report OAS/CSI/68.27.

Wade, T., R. Claassen, and S. Wallander. 2015 Conservation-practice adoption rates vary widely by crop and region, EIB-147. Washington, DC: USDA Economic Research Service.

Wang, J., G. Lü, X. Guo,Y.Wang, S. Ding, and D. Wang. 2015. Conservation tillage and optimized fertilization reduce winter runoff losses of nitrogen and phosphorus from farmland in the Chaohu Lake region, China. Nutrient Cycling in Agroecosystem 101(1):93-106. https://doi. org/10.1007/s10705-014-9664-3.

Wang, L., D. Flanagan, Z. Wang, and K. Cherkauer. 2018 Climate change impacts on nutrient losses of two watersheds in the Great Lakes Region. Water 10(4):442. https://doi.org/10.3390/w10040442.
Wieczorek, M.E., S.E.Jackson, and G.E. Schwarz. 2019. Select attributes for NHDPlus Version 2.1 Reach catchments and modified network routed upstream watersheds for the conterminous United States (ver 2.0, October 2019). U.S. Geological Survey data release. Reston,VA: USGS https://doi.org/10.5066/F7765D7V.

Wilhelm, S.W., J.M. DeBruyn, O. Gillor, M.R. Twiss, K. Livingston, R.A. Bourbonniere, L.D. Pickell, C.G. Trick, A.L. Dean, and R.L. McKay. 2003. Effect of phosphorus amendments on present day plankton communities in pelagic Lake Erie. Aquatic Microbial Ecology 32(3):275-285.

Yeo, I.-Y., S. Lee, A.M. Sadeghi, P.C. Beeson, W.D. Hively, G.W. McCarty, and M.W. Lang. 2014. Assessing winter cover crop nutrient uptake efficiency using a water quality simulation model. Hydrology and Earth Systems Sciences 18(12):5239-5253. https://doi.org/10.5194/ hess-18-5239-2014. 